\title{
HYDROGEOLOGY AND SELECTED WATER-QUALITY ASPECTS OF THE HUECO BOLSON AQUIFER AT THE HUECO BOLSON RECHARGE PROJECT AREA, EL PASO, TEXAS
}

By Paul M. Buszka, Robert D. Brock, and Richard P. Hooper

\section{U.S. GEOLOGICAL SURVEY}

Water-Resources Investigations Report 94-4092

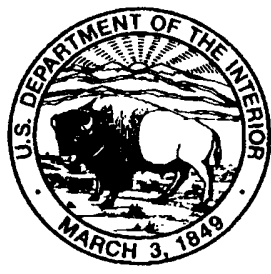

Prepared in cooperation with the

EL PASO WATER UTILITIES-PUBLIC SERVICE BOARD, TEXAS WATER DEVELOPMENT BOARD, and

U.S. DEPARTMENT OF THE INTERIOR, BUREAU OF RECLAMATION 


\section{U.S. DEPARTMENT OF THE INTERIOR \\ BRUCE BABBITT, Secretary}

U.S. GEOLOGICAL SURVEY

Gordon P. Eaton, Director

Any use of trade, product, or firm names is for descriptive purposes only and does not imply endorsement by the U.S. Government.

For additional information write to:

istrict Chief

U.S. Geological Survey 8011 Cameron Rd.

Austin, TX 78754-3898
Copies of this report can be purchased from:

U.S. Geological Survey

Earth Science Information Center

Open-File Reports Section

Box 25286, Mail Stop 517

Denver Federal Center

Denver, CO 80225-0046 


\section{CONTENTS}



\section{FIGURES}

1-3. Maps showing:

1. Location of the study area

2. Location of wells in northeast El Paso in and near the Hueco Bolson Recharge Project area

3. Location of hydrogeologic sections

4. Hydrogeologic sections $A-A^{\prime}$ and $B-B^{\prime}$ in the Hueco Bolson Recharge Project area, El Paso, Texas

5. Map showing hydraulic-conductivity distribution in the Hueco bolson aquifer

6. Map showing potentiometric surface of the Hueco bolson aquifer, January 1990

7. Graphs showing cumulative volumes of injected water from the Hueco Bolson Recharge Project area, El Paso, Texas, water produced from adjacent wells, and the cumulative difference between injected and produced volumes

8. Graphs showing nitrate and chloride concentrations in ground water in and near the Hueco Bolson Recharge Project area. El Paso, Texas, for (A) irrigation-affected water from well 5-602 and irrigation-water volumes applied to a former dairy farm, and (B) saline water from well 5-303

9-13. Mixing diagrams showing the chemistry of water samples from wells in and near the Hueco Bolson Recharge Project area, El Paso, Texas, for (A) end members, and (B) ground-water samples with respect to potential tracers of injected water for:

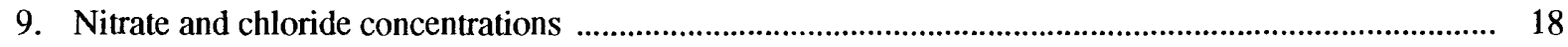

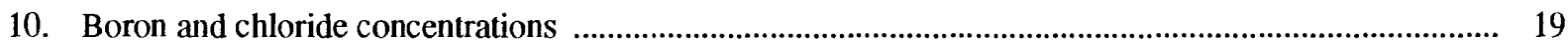

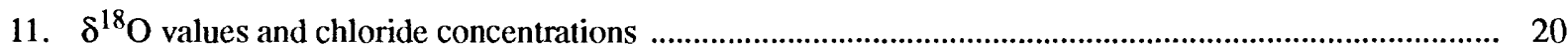

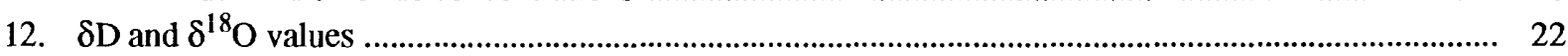

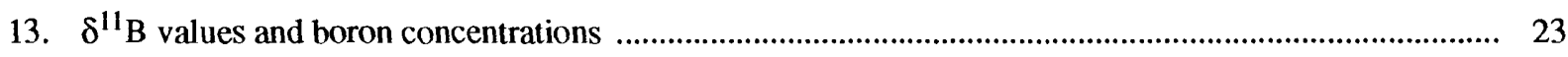

14. Graphs showing observed and predicted concentrations from end-member mixing analysis for tracer constituents in water samples from wells in and near the Hueco Bolson Recharge Project area, El Paso, Texas 
15. Map showing distribution of fractions of injected water and concentrations of chloroform and trihalomethane compounds in water samples

16. Graphs showing comparison of fractions of injected water with concentrations of trihalomethane compounds among samples from wells in the Hueco Bolson Recharge Project area, El Paso, Texas:

A. Wells 6-406, 6-405, and 6-402

B. Wells 5-620, 5-621, 5-622, and 5-604

C. Wells 5-624, 5-625, 5-626, and 5-603

\section{TABLES}

1. Calculated average linear ground-water velocities in the Hueco Bolson Recharge Project area, January 1991

2. Selected water-quality properties and constituent concentrations in injected water and ground water in and near the Hueco Bolson Recharge Project area

3. Sampling information, ratios of nitrogen isotopes $\left(\delta^{15} \mathrm{~N}\right)$, and concentrations of nutrients in water from selected wells in and near the Hueco Bolson Recharge Project area, 1988-91

4. Calculated fractions of end members contributing to ground-water chemistry in and near the Hueco Bolson Recharge Project area

5. Apparent breakthrough velocity of injected water between selected wells in the Hueco Bolson Recharge Project area 32

6. Physical and chemical properties of trihalomethane compounds 34

\section{CONVERSION FACTORS, VERTICAL DATUM, ABBREVIATED WATER-QUALITY UNITS, AND ABBREVIATIONS}

\begin{tabular}{|c|c|c|}
\hline Multiply & By & To obtain \\
\hline acre & 4,047 & square meter \\
\hline acre-foot (acre-ft) & 1,233 & cubic meter \\
\hline acre-foot per year (acre-ft/yr) & 1,233 & cubic meter per year \\
\hline foot $(\mathrm{ft})$ & 0.3048 & meter \\
\hline foot per day $(\mathrm{ft} / \mathrm{d})$ & 0.3048 & meter per day \\
\hline foot squared per day $\left(\mathrm{ft}^{2} / \mathrm{d}\right)$ & 0.09290 & meter squared per day \\
\hline gallon (gal) & 3.785 & liter \\
\hline gallon per minute (gal/min) & 0.06308 & liter per second \\
\hline inch (in.) & 25.4 & millimeter \\
\hline mile (mi) & 1.609 & kilometer \\
\hline mile squared $\left(\mathrm{mi}^{2}\right)$ & 2.590 & square kilometer \\
\hline million gallons (Mgal) & 3,785 & cubic meter \\
\hline million gallons per day (Mgal/d) & 0.04381 & cubic meter per second \\
\hline \multicolumn{3}{|c|}{ Temperature } \\
\hline degree Celsius $\left({ }^{\circ} \mathrm{C}\right)$ & ${ }^{\circ} \mathrm{F}=1.8 \times\left({ }^{\circ} \mathrm{C}+32\right)$ & degree Fahrenheit $\left({ }^{\circ} \mathrm{F}\right)$ \\
\hline
\end{tabular}

Sea level: In this report, "sea level" refers to the National Geodetic Vertical Datum of 1929--a geodetic datum derived from a general adjustment of the first-order level nets of the United States and Canada, formerly called Sea Level Datum of 1929. 
Per mil: A unit expressing the ratio of stable-isotopic abundances of an element in a sample to those of a standard material. Per mil units are equivalent to parts per thousand. Stable-isotopic ratios are calculated as follows:

$$
\delta X=\left(\frac{R(\text { sample })}{R(\text { standard })}-1\right) \times 1,000
$$

where $\mathrm{X}$ is the heavier stable isotope, and

$\mathrm{R}$ is the ratio of the heavier, less abundant stable isotope to the lighter stable isotope in a sample or standard.

The $\delta$ values for stable-isotopic ratios discussed in this report are referenced to the following standard materials:

\begin{tabular}{lll}
\hline Element & \multicolumn{1}{c}{$\mathbf{R}$} & Standard identity and reference \\
\hline oxygen & oxygen-18/oxygen-16 $\left(\delta^{18} \mathrm{O}\right)$ & Vienna-Standard Mean Ocean Water (Fritz and Fontes, 1980, p. 11) \\
hydrogen & hydrogen-2/hydrogen-1 or deuterium/protium $(\delta \mathrm{D})$ & $\begin{array}{c}\text { Vienna-Standard Mean Ocean Water (Fritz and Fontes, 1980, p. 13) } \\
\text { boron }\end{array}$ \\
boron-11/boron-10 $\left(\delta^{11} \mathrm{~B}\right)$ & $\begin{array}{c}\text { National Bureau of Standards-Standard Reference Material 951 } \\
\text { (Bassett, 1990) }\end{array}$ \\
nitrogen & nitrogen-15/nitrogen-14 $\left(\delta^{15} \mathrm{~N}\right)$ & $\begin{array}{c}\text { Standard atmospheric nitrogen, referenced to National Bureau of } \\
\text { Standards, NBS-14 nitrogen gas (Fritz and Fontes, 1980, p. 16) }\end{array}$
\end{tabular}

\section{Abbreviated water-quality units:}

$\mu \mathrm{g} / \mathrm{L}$, microgram per liter $\mathrm{mg} / \mathrm{L}$, milligram per liter

ng/L, nanogram per liter

\section{Abbreviations:}

EMMA, end-member mixing analysis

FHWRP, Fred Hervey Water Reclamation Plant

ft-MSL, feet above mean sea level

HBRP, Hueco Bolson Recharge Project

$\mathrm{mV}$, millivolt

$\mathrm{N}$, nitrogen

ohm-m, ohmmeter

THM, trihalomethane

USGS, U.S. Geological Survey 


\title{
Hydrogeology and Selected Water-Quality Aspects of the Hueco Bolson Aquifer at the Hueco Bolson Recharge Project Area, El Paso, Texas
}

\author{
By Paul M. Buszka, Robert D. Brock, and Richard P. Hooper
}

\section{Abstract}

Samples of ground water and tertiarytreated water were evaluated to determine the distribution of injected water and trihalomethane compounds in the Hueco bolson aquifer near El Paso, Texas. Chloride and nitrate concentrations and oxygen-18/oxygen- $16\left(\delta^{18} \mathrm{O}\right)$ values were used with end-member mixing analysis to estimate the fractional contributions of injected water, irrigation-affected water, saline ground water, and freshwater to ground-water chemistry.

Several laterally continuous sand and gravel layers are the principal water-yielding lithologies in the aquifer. The potentiometric surface sloped toward the south and southwest during January 1990. Average linear ground-water velocities were as large as 1.4 feet per day near the zone of largest hydraulic conductivity and were substantially smaller farther south and east.

Ground-water samples from as far as 2,900 feet from an injection well contained injectedwater tracers and trihalomethane compounds. Ground-water samples with injected-water tracers and no trihalomethane compounds may indicate infiltration from septic systems or oxidation ponds. Apparent breakthrough velocities of injected water in the aquifer ranged from 0.13 to 1.3 feet per day. Irrigation-affected water and saline water also were identified in water from several wells.

Ground-water transport of bromoform and dibromochloromethane is attenuated relative to injected water, chloroform, and dichlorobromomethane. Microbial transformation of bromoform and dibromochloromethane probably was responsible for their disappearance from ground water. Chloroform and dichlorobromomethane concentrations were affected principally by advective and dispersive transport of injected water.

\section{INTRODUCTION}

To supplement supplies of potable water, the El Paso Water Utilities-Public Service Board has injected tertiary-treated, reclaimed municipal wastewater into the Hueco bolson aquifer at the Hueco Bolson Recharge Project (HBRP) area in northeastem El Paso, Texas (fig. 1). From May 1985 to March 1991, the El Paso Water Utilities-Public Service Board injected about 8.07 billion gal of reclaimed water into the Hueco bolson aquifer (White and Sladek, 1990, p. 4; Roger Sperka, El Paso Water Utilities-Public Service Board, written commun., 1991). In 1990, the U.S. Geological Survey (USGS), in cooperation with the El Paso Water Utilities-Public Service Board, Texas Water Development Board, and U.S. Department of the Interior, U.S. Bureau of Reclamation, began a comprehensive study of the effects on water quality that result from injecting reclaimed water into the Hueco bolson aquifer.

The HBRP was designed so that the residence time of water that is injected into the aquifer would be at least 2 years (Knorr and Cliett, 1985). Residence time is defined as the time between injection and withdrawal of water by adjacent production wells. An increased residence time can enhance removal of organic compounds, bacteria, and viruses by increasing their contact time with biotransforming and inactivating processes (Gerba and Goyal, 1985; Treweek, 1985). Thus, knowing the residence time of injected 


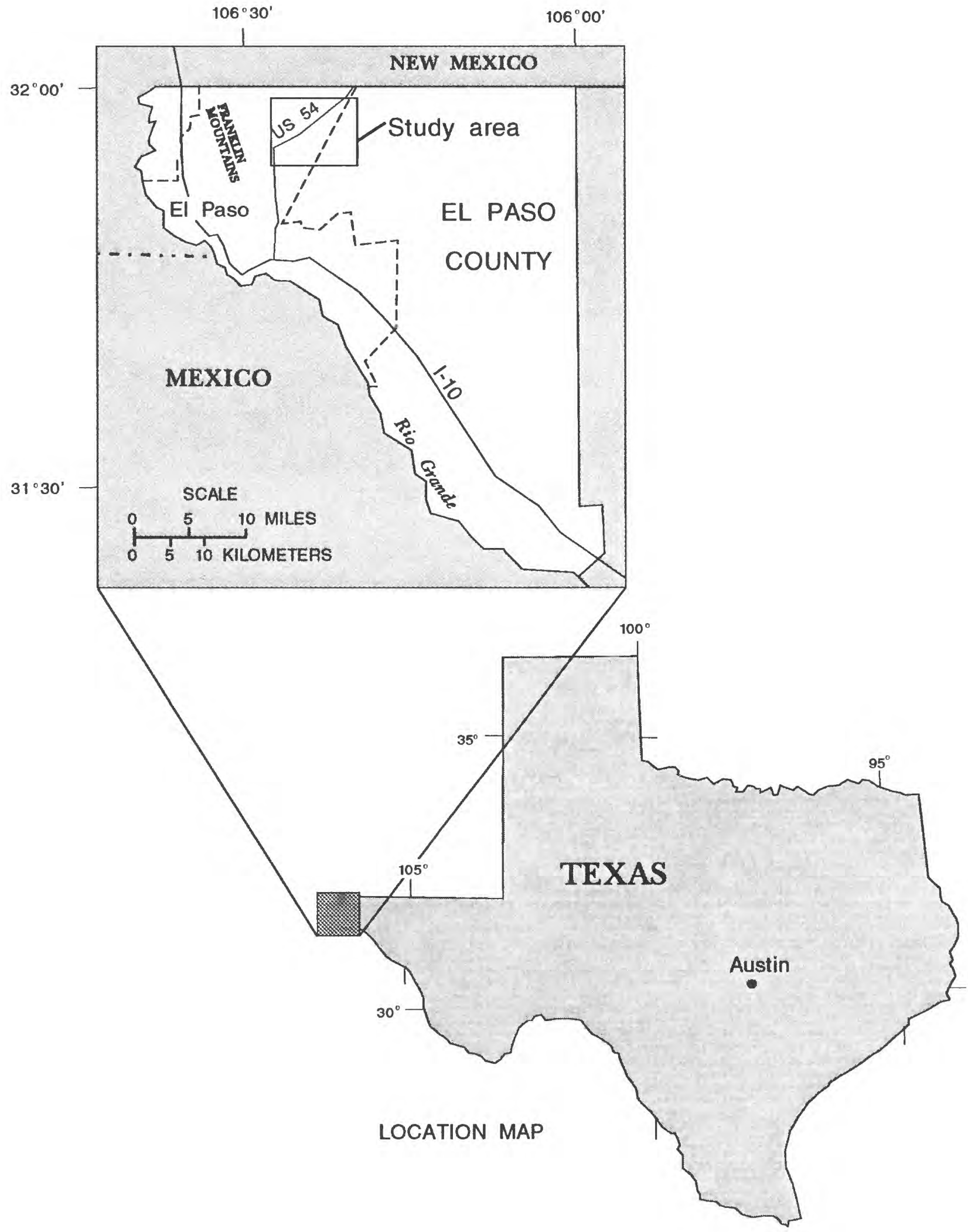

Figure 1. Location of the study area. 
water in the aquifer can be useful in determining injection effects on ground-water quality.

Injected water can be distinguished from ambient. fresh ground water by differences in water chemistry. Distinguishing injected water using conservative chemical Iracers can be difficult when additional, interfering sources of the tracers are present. A numerical method, end-member mixing analysis (EMMA), has heen developed to identify the contributions of different solute sources to the observed water chemistry (Christopherson and others, 1990); Hooper and others, 199()). The EMMA method also can be applied to determine the fraction of injected water in a sample withdrawn from a production well. Whether or not geochemical or biological processes that affect potentially reactive constituents are operating can be ascertained by comparing ohserved concentrations of the potentially reactive constituents to the conservative fraction of injected water calculated using the EMMA method.

The presence and transport of trihalomethane (THM) compounds in ground water is an important issue in reclaimed-water-injection projects such as the HBRP. Wastewater entering the HBRP is treated by several tertiary processes and is chlorinated before being injected into the aquifer. Annual-mean concentrations of dissolved organic carbon in injected water from the HBRP (before injection) have ranged from 0.78 to $0.92 \mathrm{mg} / \mathrm{L}$ (White and Sladek, 1990, p. 35). Chlorination of waters that contain organic carbon can create THM compounds, including the suspected carcinogens: chloroform, dichlorobromomethane, dibromochloromethane, and bromoform (Thurman, 1985). Total THM concentrations in samples of injected water (before injection) collected between 1985 and 1988 ranged from 10 to $26 \mu \mathrm{g} / \mathrm{L}$ (Roger Sperka, El Paso Water Utilities-Public Service Board, written commun., 1990). The THM compounds in these analyses were mainly bromoform and dibromochloromethane. The maximum contaminant level for total THM compounds in public water systems is $100 \mu \mathrm{g} / \mathrm{L}$ and may be reduced to $25 \mu \mathrm{g} / \mathrm{L}$ by 1995 (U.S. Environmental Protection Agency, 1990).

An understanding of biological and geochemical processes affecting THM compounds injected with reclaimed water into the aquifer is important to define their environmental persistence. Previous studies indicate that THM compounds are affected by sorptive and biotransforming processes. Sorptive retardation of THM compounds has been determined in laboratory and field studies under aerobic conditions (Curtis and others, 1986; Mackay and others, 1986; Roberts and others, 1986). Sorptive retardation of THM compounds becomes more effective where the fraction by weight of solid-phase organic carbon in the aquifer is greater than 0.01 (Schwarzenbach and others, 1983). Laboratory studies indicate substantial removal of the THM compounds by biotransformation under methanogenic and denitrifying conditions but not under aerobic conditions (Bouwer and others, 1981; Schwarzenbach and others, 1983; Bouwer and McCarty, 1984).

\section{Purpose and Scope}

This report presents the results of a study of the hydrogeology and selected water-quality aspects of the Hueco bolson aquifer in the HBRP area at El Paso. The characteristics of local hydrogeology that are discussed as they pertain to solute transport include aquifer properties, ground-water flow, and sources of humanaffected recharge and solutes to ground water. Also included are selected water-quality aspects of the HBRP area, as determined from the water chemistry of injected water and other end members, and from the water chemistry of end-member tracers. The distribution of injected water and other end members in ground water and the distribution of THM compounds in ground water are discussed.

\section{Acknowledgment}

The authors gratefully acknowledge Dr. Randy Bassett, Department of Hydrology and Water Resources, University of Arizona, for his analysis of boron isotope data and advice regarding the interpretation of those data.

\section{Description of the Study Area}

The HBRP area (fig. 2) is about $3 \mathrm{mi}$ south of the Texas-New Mexico State line in the northeastern part of El Paso. The study area comprises about $41.5 \mathrm{mi}^{2}$ (fig. 1). Ground-water chemistry was studied around the HBRP area that extends about $1.5 \mathrm{mi}$ north, $1.5 \mathrm{mi}$ south, $0.8 \mathrm{mi}$ east, and $0.3 \mathrm{mi}$ west of an array of injection wells (figs. 1,2). The Hueco bolson aquifer is in an alluvial basin known as the Hueco bolson. The term 

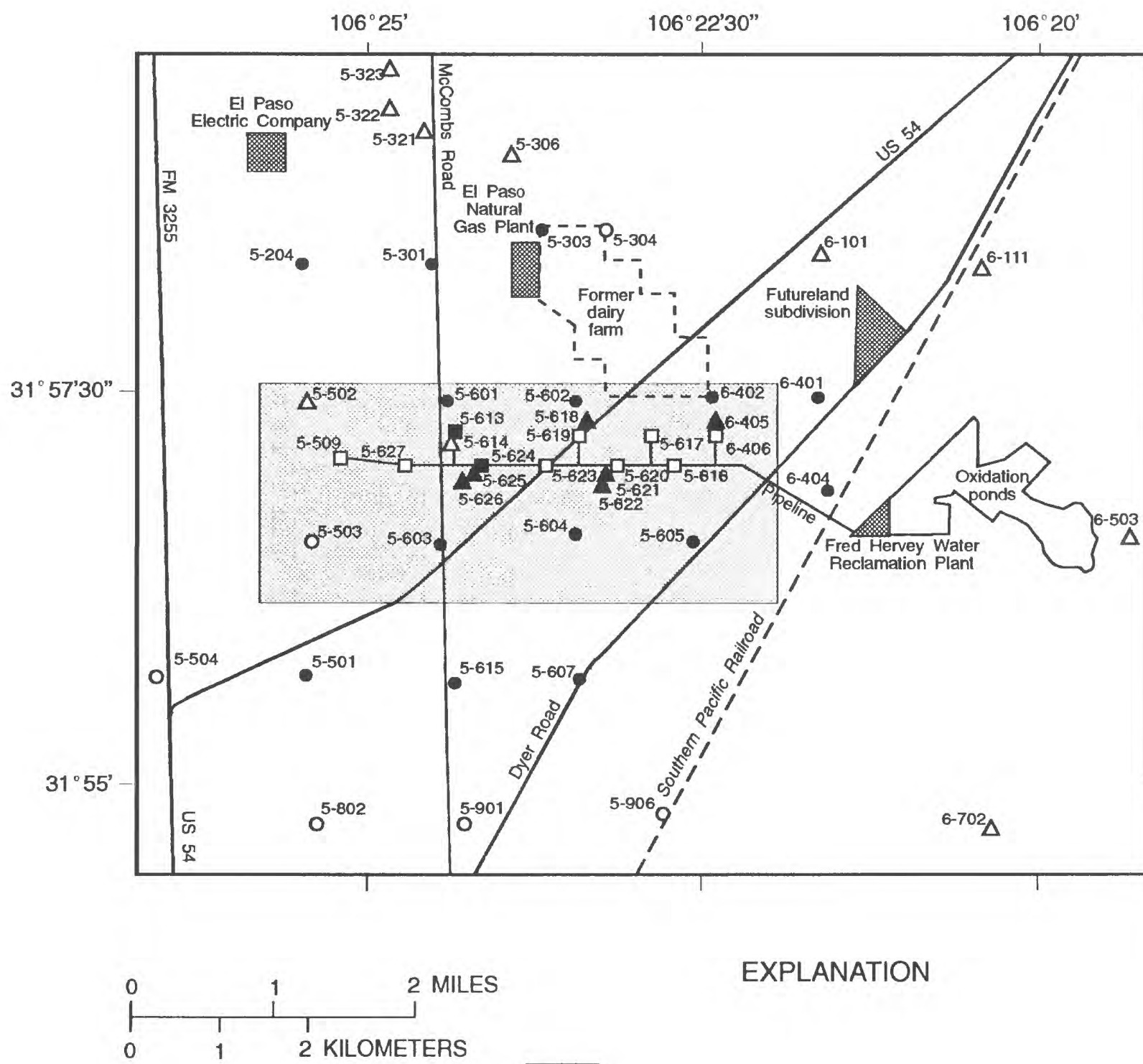

EXPLANATION

HUECO BOLSON RECHARGE PROJECT AREA

5-509 $\square$ INJECTION WELL AND NUMBER

5-613 SAMPLED INJECTION WELL AND NUMBER

5-614 $\triangle$ OBSERVATION WELL AND NUMBER

6.405 SAMPLED OBSERVATION WELL AND NUMBER

5-9010 PRODUCTION WELL AND NUMBER

5-204 SAMPLED PRODUCTION WELL AND NUMBER

Note: Well number consists of last four digits of the Texas well-numbering system

Figure 2. Location of wells in northeast El Paso in and near the Hueco Bolson Recharge Project area. 
"bolson" pertains to the sediment-filled, intermontane basin surrounded by the Franklin Mountains on the west, a relatively low topographic divide north of the Texas-New Mexico border, the Hueco Mountains on the east, and the EI Paso and Juarez valleys on the south (White, 1983, fig. 1; p. 4).

The HBRP facilities include a tertiary-wastewater-treatment plant, the Fred Hervey Water Reclamation Plant (FHWRP), with a $10 \mathrm{Mgal} / \mathrm{d}$ capacity and a well lield where reclaimed water is injected into the aquifer (Knorr and Cliett, 1985). Wastewater processed hy the plant originates principally from domestic and commercial sources. Wastewater is treated by (1) primary clarification, (2) hiological treatment under acrobic and anaerobic conditions with granular activated carhon, (3) lime treatment, (4) ozone disinfection, (5) $\mathrm{pH}$ adjusted filtration through granularactivated carbon, and (6) chlorination to produce reclaimed water. The reclaimed water meets or exceeds the primary drinking water standards of the U.S. Environmental Protection Agency (1990). The reclaimed water is injected into the saturated zone of the Hueco bolson aquifer through 10 wells (fig. 2).

Several past and present land uses near the HBRP site also contribute human-affected recharge to the Hueco bolson aquifer (White, 1983; Roger Sperka, El Paso Water Utilities-Public Service Board, written commun., 1992). A 622-acre former dairy farm located north of the eastern part of the HBRP area (fig. 2) was irrigated intensely from 1956 to 1975 to produce corn for silage (Roger Sperka, El Paso Water UtilitiesPublic Service Board, written commun., 1992). Unlined oxidation ponds west of well 6-503 at the FHWRP (fig. 2) have contributed recharge to the aquifer since about 1963. Other small-volume sources of recharge to the aquifer include a seepage pond for cooling water and wastewater from metal plating at the El Paso Natural Gas Plant and residential septic systems in the Futureland subdivision (fig. 2).

\section{Methods of Study}

\section{Hydrogeologic-Data Collection}

Strata thicknesses and lithologies of aquifer sediments were classified using borehole-geophysical data from 16-in. and 64-in. normal resistivity, spontaneous potential, and natural gamma radiation logs (Roger Sperka, El Paso Water Utilities-Public Service Board, written commun., 1991; Brock and others, 1994). The minimum thickness that could be logged accurately by a 16 -in. normal resistivity $\log$ was $2.5 \mathrm{ft}$. A $15 \mathrm{ohm}-\mathrm{m}$ or larger response on the 16-in. normal log, in the same interval where the spontaneous potential response either remained constant or increased, indicated a sand unit. Lesser responses of the 16-in. normal log, with constant or increased spontaneous potential log response, indicated clay, sandy clay, or silty clay strata. Sand units containing brackish water were identified using a combination of (1) a $10-\mathrm{mV}$ decrease in spontaneous potential log response relative to adjacent sand units, and (2) increases in 16-in. normal resistivity log response of 5 to $10 \mathrm{ohm}-\mathrm{m}$ relative to adjacent, suspected clay units. Thicknesses of sand layers classified in this manner were used to calculate vertically averaged values of hydraulic conductivity from published and unpublished transmissivity data, according to the following equation:

$$
\mathrm{K}=\frac{\mathrm{T}}{\mathrm{b}} \text {, }
$$

where $\mathrm{K}=$ hydraulic conductivity, in feet per day;

$\mathrm{T}=$ transmissivity, in feet squared per day; and $\mathrm{b}=$ thickness of sand layers, in feet.

Water-level measurements were made in observation wells and selected production wells during January 1991 (Roger Sperka, El Paso Water Utilities-Public Service Board, written commun., 1991). The waterlevel measurements were made while injection wells were operating and nearby production wells were not pumping.

\section{Water Sampling and Analysis}

Water samples were collected during August and September of 1990 and 1991 from selected injection, observation, and production wells in the study area (fig. 2). Chemical analyses of 50 ground-water samples collected from 6 observation wells, 14 water-supply or "production" wells, and from a withdrawal test of an injection well were used for this study. Eight samples of tertiary-treated injected water that were collected from two injection wells also were used. Samples were analyzed for physical properties, major cations and anions, trace elements, nutrients, and the stable-isotopic ratios of boron, hydrogen, and oxygen (Brock and others, 1994). Samples were collected for organic analyses that included suspended organic carbon, dissolved 
organic carbon, volatile organic compounds, and semivolatile organic compounds. The aerobic and facultative anaerobic bacterial populations were determined for selected samples. Information regarding types of samples collected at each well, methods of sample collection and analysis, and water-quality data are presented in Brock and others (1994). Selected constituents from these data are used in this report to characterize tracer constituents, redox conditions, and THM compounds in injected water, in other solute sources, and in ambient ground water. All data discussed in this report met USGS quality-assurance objectives for accuracy, precision, completeness, and representative character (Brock and others, 1994).

\section{End-Member Mixing Analysis}

The evaluation of mixing between injected water and other ambient waters begins with "mixing diagrams" that use water-chemistry analyses to define distinct solute sources referred to as end members (Christopherson and others, 1990). The diagrams are linear $x-y$ plots of all constituents suspected to be indicators of conservative mixing in ground water (such as chloride and nitrate concentrations). Nitrite was not detected at concentrations greater than the reporting limit of $0.01 \mathrm{mg} / \mathrm{L}$ as nitrogen $(\mathrm{N})$ in water samples collected from wells at the HBRP during 1990 and 1991 (Brock and others, 1994). Therefore, in this report, concentrations of nitrite plus nitrate as $\mathrm{N}$ are discussed and referred to as nitrate concentrations. If the end members mix conservatively to produce the ambient ground-water chemistry, the observed constituent concentrations in the ground water will plot close to the polygon formed by drawing lines that connect the several end members.

The fractional components of " $n$ " end members of a ground-water sample as characterized by " $\mathrm{m} "$ chemical species can be determined by solving " $n$ " simultaneous linear equations:

$$
\begin{array}{ccc}
\sum_{i=1}^{m} & \sum_{j}^{n} & \\
m_{i=2}^{m} & C_{1, j} X_{j}=G_{1} \\
& \sum_{j}^{n} & \\
& \cdot & \\
& & \\
& &
\end{array}
$$

$$
\begin{aligned}
& \sum_{i=m}^{m} \sum_{j}^{n} \quad C_{i, j} X_{j}=G_{i} \\
& \text { n } \\
& \sum_{j=1} X_{j}=1
\end{aligned}
$$

where $\mathrm{m}=$ number of chemical species;

$\mathrm{i}$ = a chemical species;

$\mathrm{n}=$ number of end members;

$\mathrm{j}=$ an end member;

$\mathrm{C}_{\mathrm{i}, \mathrm{j}}=$ concentration of chemical-species $\mathrm{i}$ in endmember $\mathrm{j} ; \mathrm{i}=1, \ldots . ., \mathrm{m}$;

$X_{j}=$ fraction of end-member $j ; j=1, \ldots, n$; and

$\mathrm{G}_{\mathrm{i}}=$ concentration of chemical-species $\mathrm{i}$ in the ground-water sample.

The EMMA method requires that $\mathrm{m} \geq \mathrm{n}-1$. In this study, $m=n-1$. For applications where $m>n-1$, solution of the simultaneous equations is more complex, involving linear least squares estimation (Draper and Smith, 1981; Wolfram, 1988).

Each end member is described by using the concentrations of conservative constituents in samples that represent the end member. The fractional component each end member adds to a water sample is meaningful only if the end member is sufficiently different in concentration from other end members and if the concentrations of each solute within an end member are sufficiently constant in space and time.

The mixing diagrams alone cannot validate conservative mixing but can be used to invalidate conservative mixing for the observed end members. For example, if a water analysis plots substantially outside the polygon described by the end members on the $x-y$ plot, at least one end member is incorrectly characterized, or missing, or the end members do not mix conservatively.

The match between the observed concentrations and the concentrations predicted by the EMMA method also provides a test of the choice of end members. The match was evaluated by a visual fit of the data with a 1-to-1 relation between observed and predicted concentrations. If the slope of the predictions compared to the observations does not substantially coincide with the 1-to-1 relation for one or more of the solutes, the end-member composition is questionable. 


\section{HYDROGEOLOGY}

The study area is underlain by unconsolidated alluvial deposits of interbedded gravel, sand, clay, and silt of the Hueco bolson (Richardson, 1909). These sediments compose the Hueco bolson aquifer and range in thickness from less than $100 \mathrm{ft}$ near the Franklin Mountains to about $9,000 \mathrm{ft}$ within 4 mi east of the Franklin Mountains (Meyer, 1976, p. 5). The thickest section of the alluvial fill lies in a trough that is oriented along and adjacent to the eastern base of the Franklin Mountains (White, 1983). The sand and gravel strata contain quartz, jasper, feldspar, and clasts of basalt, rhyolite, and sandstone (Ted Small, U.S. Geological Survey, written commun., 1992). Clay minerals in sediments of the Hueco bolson are mostly montmorillonite with lesser amounts of illite and kaolinite (Garza and others, 1980).

The zones of the Hueco bolson aquifer that are used for injection mostly contain freshwater with a dissolved-solids concentration of less than $1,000 \mathrm{mg} / \mathrm{L}$ (White, 1983, p. 38). The freshwater zone of the aquifer extends from the water table to depths ranging from about $200 \mathrm{ft}$ to about $700 \mathrm{ft}$ (Meyer, 1976, p. 13). Parts of the aquifer to the north-northeast of the HBRP area and below the freshwater zone contain slightly to moderately saline water (dissolved-solids concentration 1,000 to $10,000 \mathrm{mg} / \mathrm{L}$ ).

The principal lithologies in the freshwater part of the aquifer within the HBRP area are several laterally continuous layers of sand and gravel or silt and clay, with smaller, discontinuous interbeds of these lithologies (figs. 3,4). The sand and gravel units are the chief water-yielding strata of the aquifer. Many of the smaller layers may grade laterally into sediments of differing texture over distances of less than $100 \mathrm{ft}$. The overall lithologic continuity indicates that hydraulic continuity exists between the injection and production wells. The thicknesses of the sand and gravel layers, and the silt and clay layers indicate that their deposition principally was from alluvial fans extending eastward from the Franklin Mountains. The alluvial deposition patterns have been modified substantially by stream erosion and deposition. The fluvial processes are indicated by the smaller, laterally discontinuous strata.

\section{Aquifer Properties and Ground-Water Flow}

The vertically averaged hydraulic conductivity of sand layers in the aquifer near the HBRP area ranged from $21 \mathrm{ft} / \mathrm{d}$ at well $5-501$ to $88 \mathrm{ft} / \mathrm{d}$ at well 5-619 (Brock and others, 1994). The values were calculated by dividing the transmissivity value at each well by the composite thickness of sand layers determined from borehole-geophysical data. Hydraulic conductivity of the aquifer (fig. 5) is largest along a zone hetween wells 5-303, 5-602, 5-619, and 5-603; it decreases across the HBRP area toward the south and west. The true horizontal and vertical distributions of hydraulic conductivity in the sand layers probably are more complex than shown in figure 5. Lateral and vertical changes in sediment composition and hydraulic conductivity over short distances are typical of alluvial sediments of the Hueco bolson (White, 1983). Estimates of specific yield ranging between 0.15 and 0.22 have heen used to simulate ground-water flow near the HBRP (Garza and others, 1980, p. 10).

The ground-water-flow system in the study area is controlled mainly by natural and human-affected sources of recharge and by discharge from watersupply wells (White, 1983). Natural sources of recharge to the Hueco bolson aquifer in the El Paso area are infiltration of runoff along the eastern base of the Franklin Mountains, streamflow from the Rio Grande, and ground-water flow from north of the Texas-New Mexico border (White, 1983, p. 29 and fig. 14). Major, documented human-affected sources of recharge have included the HBRP injection wells, irrigation-affected seepage from the former dairy farm, and seepage from the FHWRP oxidation ponds (fig. 2; White, 1983). The regional potentiometric-surface gradient throughout the area of the injection wells was south-southwest during January 1990 (fig. 6). The potentiometric-surface gradient during this period was typical of those determined during injection operations at the HBRP area between 1986 and 1991 (Roger Sperka, El Paso Water Utilities-Public Service Board, written commun., 1991). Production wells 5-601, 5-603, 5-604, and 6-402, used for gradient calculations, are pumped mainly during the summer.

The depth to water near the HBRP area ranged from $277.25 \mathrm{ft}$ below land surface at well 6-50) 10 $384.4 \mathrm{ft}$ below land surface at well 5-303 during January 1990 (Roger Sperka, El Paso Water Utilities-Public Service Board, written commun., 1991). The depth to water below the unlined oxidation ponds was assumed 


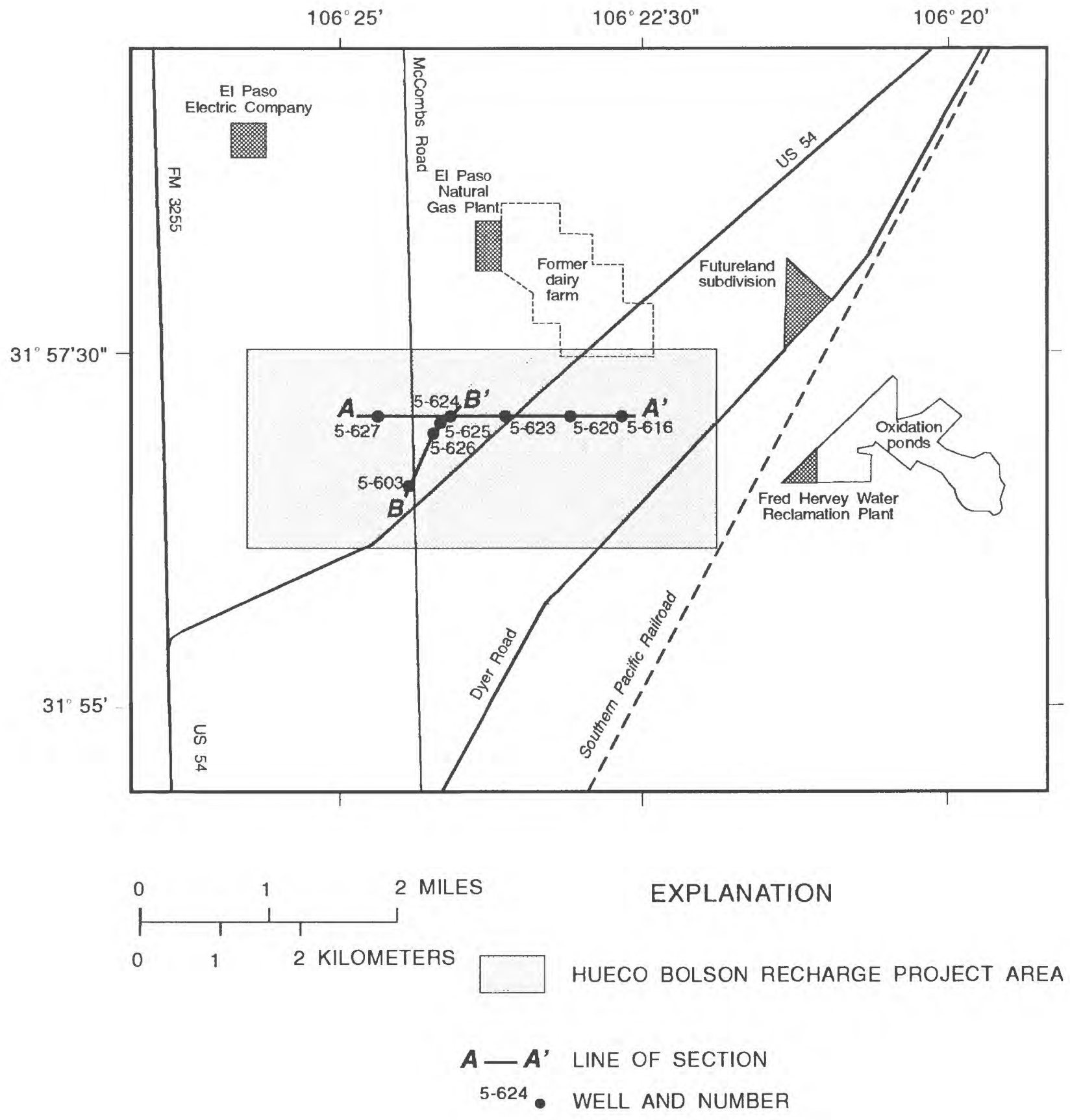

Figure 3. Location of hydrogeologic sections. 

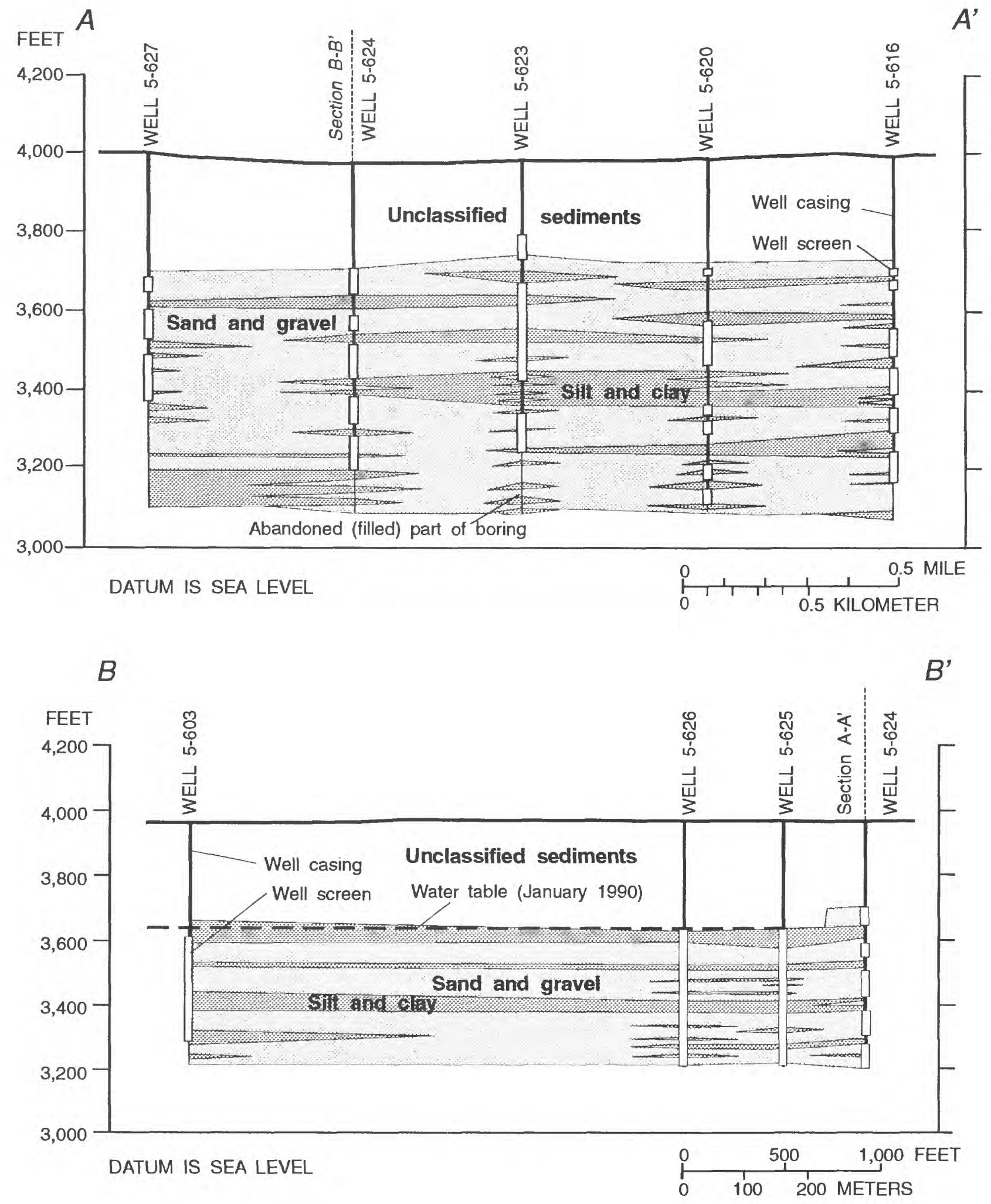

Figure 4. Hydrogeologic sections $A-A^{\prime}$ and $B-B^{\prime}$ in the Hueco Bolson Recharge Project area, El Paso, Texas. 

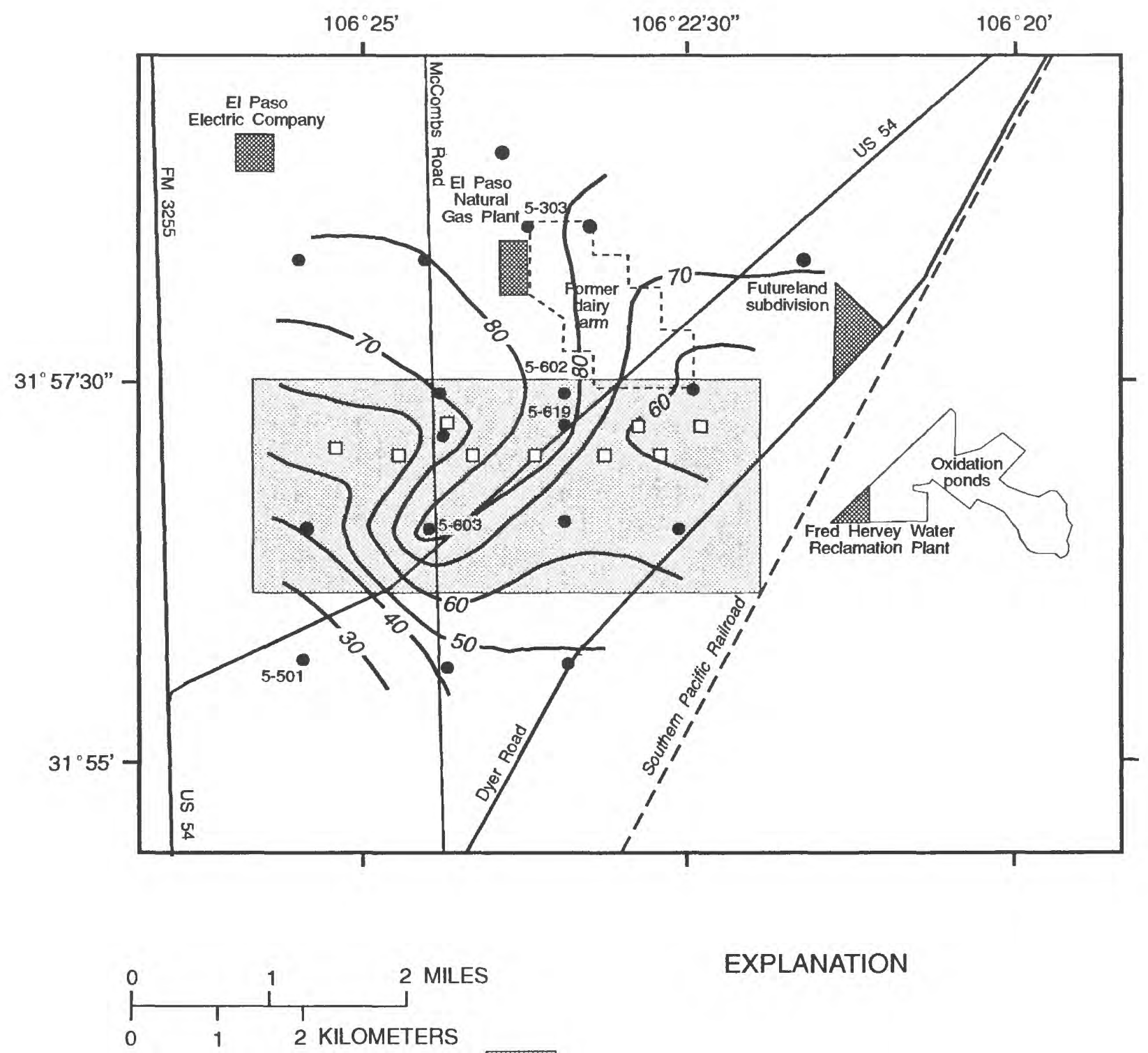

EXPLANATION

HUECO BOLSON RECHARGE PROJECT AREA

- 30 - Line of equal Vertically aVERAGed

HYDRAULIC CONDUCTIVITY - Interval 10 feet per day.

5.501. CONTROL WELL AND NUMBER (IF CITED IN TEXT)

口 INJECTION WELL

Figure 5. Hydraulic-conductivity distribution in the Hueco bolson aquifer. 

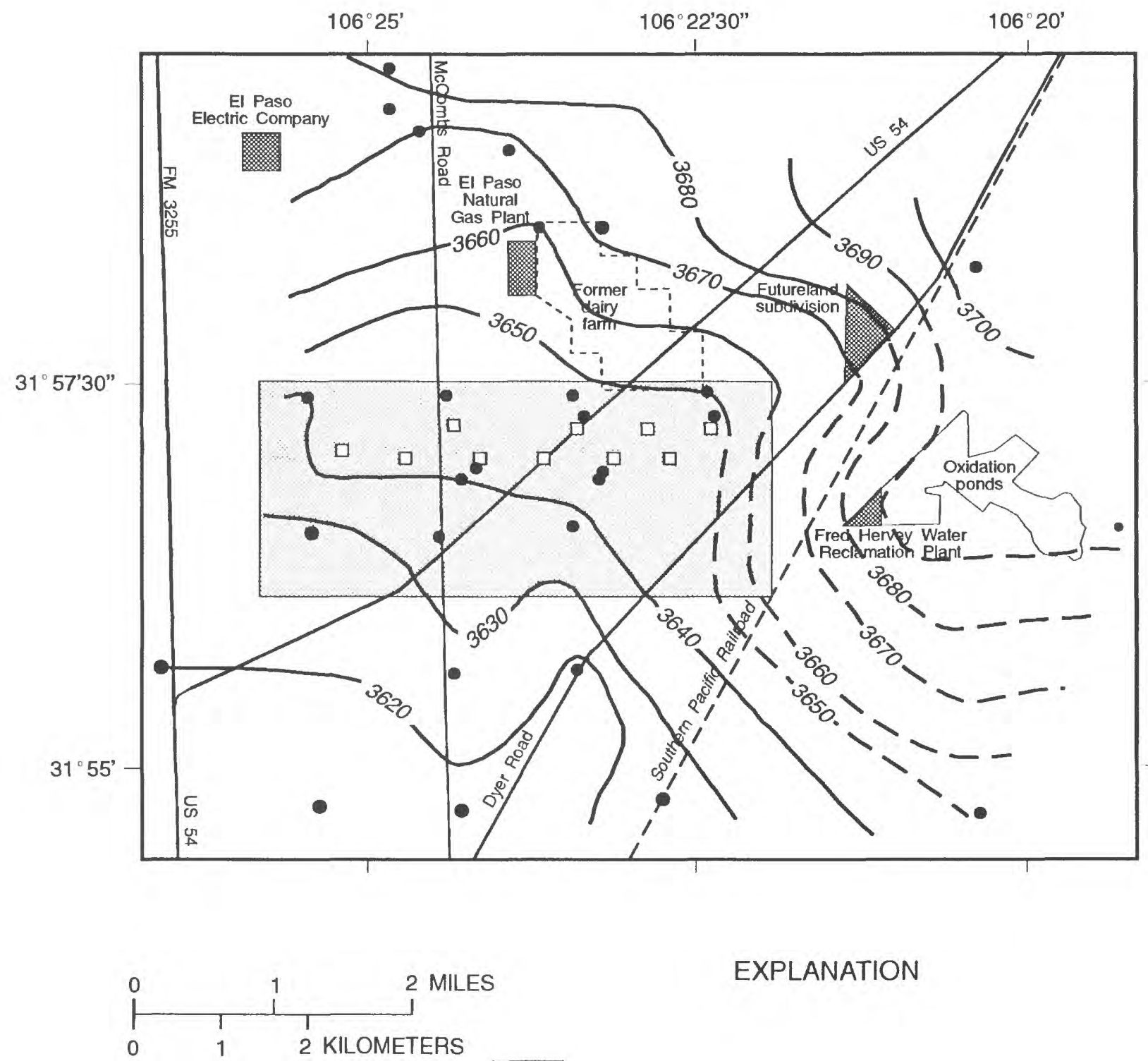

\section{EXPLANATION}

HUECO BOLSON RECHARGE PROJECT AREA

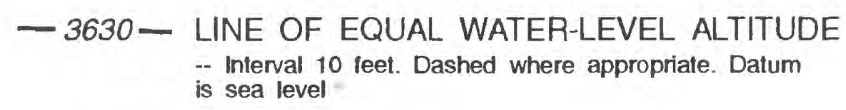

- $\quad$ CONTROL WELL

INJECTION WELL

Figure 6. Potentiometric surface of the Hueco bolson aquifer, January 1990. 
to equal the value from well 6-503. A water-table mound is assumed to exist beneath the FHWRP oxidation ponds (fig. 6).

Velocities of ground-water flow in the Hueco bolson aquifer typically are less than $1 \mathrm{ft} / \mathrm{d}$ (White, 1983). Average linear ground-water velocities near the zone of largest hydraulic conductivity near the HBRP area were calculated to be about $1.3 \mathrm{ft} / \mathrm{d}$ near wells 5602 and 5-618 and $1.4 \mathrm{ft} / \mathrm{d}$ near wells 5-625 and 5-603 (table 1). Average linear ground-water velocities were substantially smaller near wells 6-402 and 6-405 and near wells 5-621 and 5-604. Water-level measurements used for these calculations were from wells at least 300 $\mathrm{ft}$ from the nearest injection well to limit influences from short-term changes in injection rates. Garza and others (1980) calculated average linear ground-water velocities that ranged from 0.61 to $1.2 \mathrm{ft} / \mathrm{d}$. These values were obtained from computer simulations of the aquifer that assumed injection rates of 500 to 1,000 $\mathrm{gal} / \mathrm{min}$ and well-field pumping rates of 28,550 and 57,100 acre-ft/yr.

The cumulative confining effect of intermittent layers or lenses of clay causes all but the uppermost saturated zones of the aquifer to react as a semiconfined or confined aquifer when pumped. Upward llow was detected by dye-tracer testing in 37 of 40 depth intervals among six fully screened observation wells within 700 feet of the injection wells (Brock and others, 1994). Because most wells available for sampling also are screened through several hundred feet of aquifer, water samples probably represent mixing of water from different depths.

\section{Sources of Human-Affected Recharge and Solutes to Ground Water}

The principal source of human-affected recharge to the aquifer near the HBRP area is reclaimed-water injection. About 8.07 billion gal of reclaimed water were injected into the aquifer through the 10 injection wells between May 1985 and March 1991 (fig. 7). The injection wells are screened through intervals with altitudes ranging from about 3,112 to $3,708 \mathrm{ft}-\mathrm{MSL}$ at well 5-620 and about 3,179 to 3,801 ft-MSL at well 5-613 (Brock and others, 1994). During the same period, about 9.8 billion gal (fig. 7) were produced from the six adjacent production wells, 5-601, 5-602, 5-603, 5-604, 5-605, and 6-402. These production wells are screened through intervals with altitudes ranging from about
3,168 to $3,651 \mathrm{ft}-\mathrm{MSL}$ at well 5-604 and about 3,217 to 3,662 ft-MSL at well 5-605 (Brock and others, 1994). The injection wells are screened through intervals that overlap most of the range of screened intervals at the closest production wells. Results from preliminary modeling studies indicated a 6-year residence time for injected water in the aquifer, assuming piston-flow conditions (Knorr and Cliett, 1985).

Irrigation-affected water previously was a major source of recharge and dissolved solids to ground water in the study area. Irrigation of corn of the former dairy farm and the leaching of unsaturated-zone minerals by the infiltrating water caused ground water in the eastern half of the HBRP area to contain larger dissolvedsolids and nitrate concentrations than did ground water from the western part of the HBRP area (White, 1983, p. 52-63).

The com was irrigated with about 32.3 billion gal of water from the Hueco bolson aquifer from 1956 to 1975 and about 1.0 billion gal of cooling water from the El Paso Electric Company from 1965 to 1975 (White, 1983, p. 54). After consumptive use of water by the corn, an estimated 15.85 billion gal of irrigationaffected recharge reached the aquifer from about 1964 to 1978 (Lee Wilson and Associates, 1991, p. 95). The first arrival of irrigation-affected recharge at the saturated zone was observed in 1964, about 8 years after irrigation began (White, 1983).

Infiltration of wastewater from the unlined oxidation ponds at the FHWRP also is a source of recharge and solutes to ground water near the HBRP area. The ponds were used from 1962 to 1985 to evaporate and oxidize wastewater from the wastewatertreatment plant. The ponds were used after 1985 to temporarily store untreated wastewater when its volume exceeded the FHWRP's treatment capacity. Seepage from the ponds was estimated to be about 2.9 $\mathrm{Mgal} / \mathrm{d}$, from water-budget studies, or a total of $25 \mathrm{bil}$ lion gal between 1964 and 1987 (White, 1983, p. 64; Lee Wilson and Associates, 1991, RM-3, p. 96). A 1980 potentiometric-surface map indicates that ground water, and thus any wastewater-related contaminants that had reached the saturated zone, were moving away from the ponds toward the west and southwest (White, 1983, fig. 30).

Another potential source of solutes to local ground water is water from wells that penetrate the saline-water zones of the aquifer. For example, production well 5-303 is screened through the freshwater zone of the aquifer and into underlying slightly saline water 

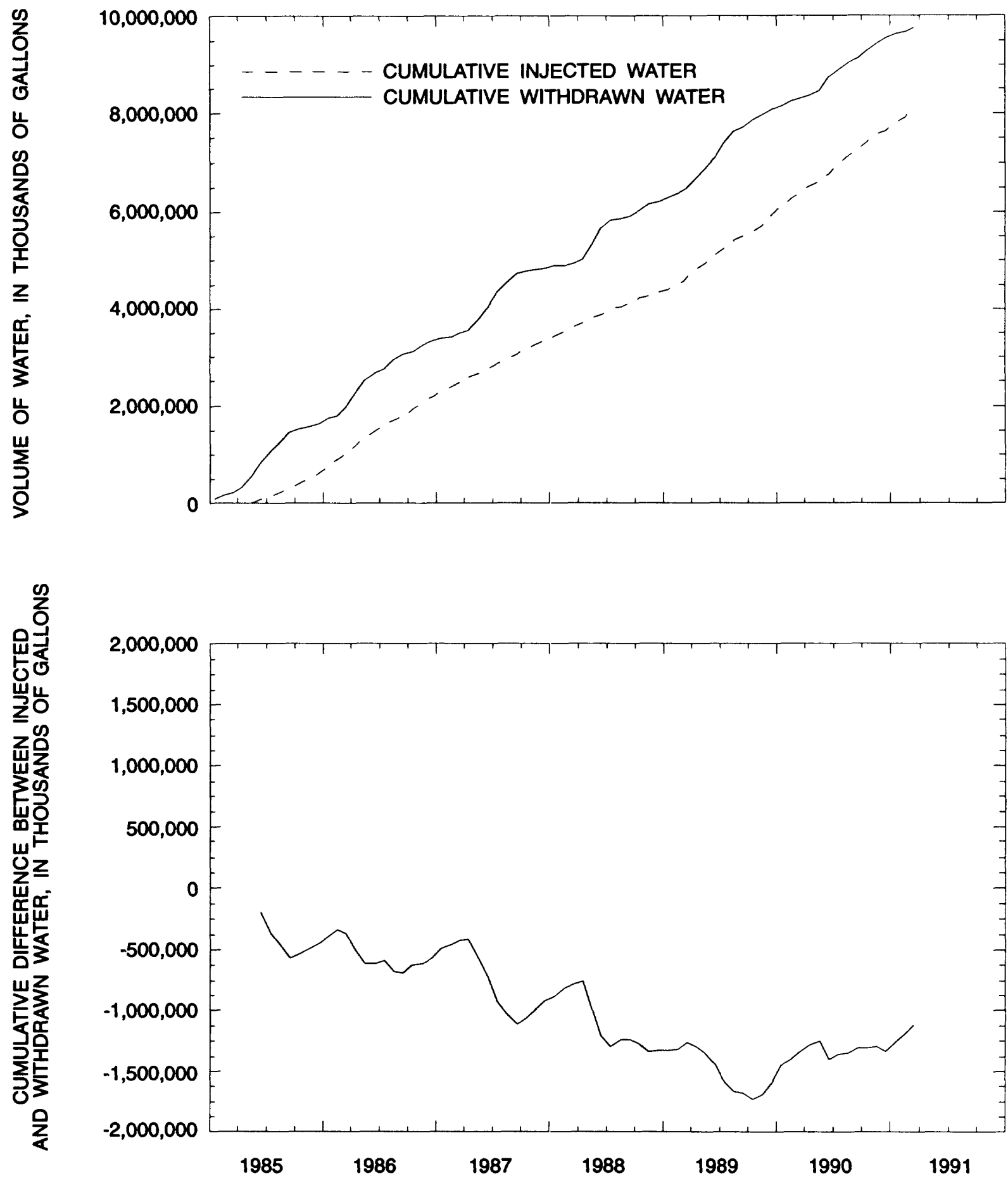

Figure 7. Cumulative volumes of injected water from the Hueco Bolson Recharge Project area, El Paso, Texas, water produced from adjacent wells, and the cumulative difference between injected and produced volumes. 
Table 1. Calculated average linear ground-water velocities in the Hueco Bolson Recharge Project area, January 1991

[ft-MSL, feet above mean sea level; ft/ft, foot per foot; $\mathrm{ft} / \mathrm{d}$, foot per day]

\begin{tabular}{|c|c|c|c|c|c|c|c|}
\hline \multicolumn{2}{|c|}{$\begin{array}{c}\text { Nearest } \\
\text { upgradient well }\end{array}$} & \multicolumn{2}{|c|}{$\begin{array}{c}\text { Nearest } \\
\text { downgradient well }\end{array}$} & \multirow{2}{*}{$\begin{array}{l}\text { Potentio- } \\
\text { metric } \\
\text { head } \\
\text { gradient } \\
(\mathrm{ft} / \mathrm{ft})\end{array}$} & \multirow{2}{*}{$\begin{array}{l}\text { Porosity } \\
\text { (decimal } \\
\text { fraction) }\end{array}$} & \multirow{2}{*}{$\begin{array}{c}\text { Hydraulic } \\
\text { conductivity } \\
\text { (ft/d) }\end{array}$} & \multirow{2}{*}{$\begin{array}{c}\text { Average } \\
\text { linear } \\
\text { ground- } \\
\text { water } \\
\text { velocity } \\
\text { (ft/d) }\end{array}$} \\
\hline Number & $\begin{array}{c}\text { Water } \\
\text { level } \\
\text { (ft-MSL) }\end{array}$ & Number & $\begin{array}{c}\text { Water } \\
\text { level } \\
\text { (ft-MSL) }\end{array}$ & & & & \\
\hline \multicolumn{8}{|c|}{ North of injection wells: } \\
\hline $6-402$ & 3,650 & $6-405$ & 3,649 & 0.0012 & 0.20 & 55 & 0.33 \\
\hline $5-602$ & 3,650 & $5-618$ & 3,646 & .0030 & .20 & 85 & 1.3 \\
\hline \multicolumn{8}{|c|}{ South of injection wells: } \\
\hline $5-621$ & 3,644 & $5-604$ & 3,638 & .0022 & .20 & 63 & .69 \\
\hline $5-625$ & 3,641 & $5-603$ & 3,631 & .0035 & .20 & 78 & 1.4 \\
\hline
\end{tabular}

${ }^{1}$ Calculated using equation 2.82 (Freeze and Cherry, 1979, p. 71).

with dissolved-solids concentrations ranging from 1,000 to $3,000 \mathrm{mg} / \mathrm{L}$ (Roger Sperka, El Paso Water Utilities-Public Service Board, written commun., 1990). Pumping-induced flow of saline water toward wells that are screened at depths near the interface between the freshwater and saline-water zones also could increase ground-water salinity.

\section{SELECTED WATER-QUALITY ASPECTS}

\section{Injected Water and Other End Members}

End members used to determine the contribution of different solute sources to ground-water chemistry were initially described using water samples representing major sources of recharge and solutes to ground water. They are:

1. Injected water--This end member represents the chemistry of treated water that is injected into the Hueco bolson aquifer by the HBRP. Samples of injected water were collected at the wellheads of injection wells 5-613 and 5-624 before injection.

2. Irrigation-affected water--This end member represents the chemistry of ground water that is affected by dissolved solids leached by infil- trating water from the irrigation of the former dairy farm. The water chemistry of the irrigation-affected water end member was defined by an analysis of a 1990 water sample from well 5-602 (fig. 8A). Increased chloride, dissolvedsolids, and nitrate concentrations in water from several wells that are downgradient from the former dairy farm were attributed to irrigationaffected infiltration (White, 1983, p. 52-64). Chloride concentrations in water from well 5-602 have ranged from 391 to $451 \mathrm{mg} / \mathrm{L}$ between 1980 and 1990 (fig. 8A; table 2, at end of report). White (1983) described the water chemistry at well 5-602 as affected by irrigation at the former dairy farm.

3. Saline water--This end member represents the chemistry of slightly saline water from below and laterally adjacent to the freshwater part of the Hueco bolson aquifer. The water chemistry of the saline-water end member was defined by an analysis of a 1991 water sample from well 5-303 (fig. 8B). The concentration of chloride in the 1991 sample $(980 \mathrm{mg} / \mathrm{L}$ ) (fig. $8 \mathrm{~B}$; table 2) is similar to those in samples of slightly saline water collected in 1955 from 836 to $857 \mathrm{ft}$ below land surface $(896 \mathrm{mg} / \mathrm{L})$ 
and from 900 to $922 \mathrm{ft}$ below land surface $(960$ $\mathrm{mg} / \mathrm{L}$ ) (Parkhill and others, 1990). The 1991 nitrate concentration is closest to the 1964 and 1970 determinations of nitrate before the effects of the dairy-farm irrigation were apparent (fig. 8B). The end-member chemistry of saline water is adequately represented by the 1991 sample.

4. Freshwater--This end member represents ground water with dissolved-solids concentrations less than $1,000 \mathrm{mg} / \mathrm{L}$ that predated the humanaffected sources of recharge described in this report. Wells with water quality meeting these conditions include 5-204 and 5-301 that are upgradient from the HBRP area and 5-501, 5-607, and 5-615 that are downgradient from the HBRP area (White, 1983, p. 60).

Samples of water from wells near the unlined oxidation ponds at the FHWRP, water from the unlined oxidation ponds, water from the seepage pond at the El Paso Natural Gas compressor station, and water from residential septic-system seepage from the Futureland subdivision either could not be sampled or were outside the scope of this project. An end-member representation of the water chemistry of infiltration from these sources therefore was not made.

\section{Water Chemistry of End-Member Tracers}

Potential chemical tracers of injected water and other solute sources in ground water were selected from among chloride, bromide, iodide, nitrate, boron, and the stable-isotopic ratios of hydrogen $(\delta D)$, oxygen $\left(\delta^{18} \mathrm{O}\right)$, and boron $\left(\delta^{11} \mathrm{~B}\right)$. A tracer is matter or energy carried by a medium that can indicate the direction and velocity of its flow in the medium (Davis and others, 1985). An ideal ground-water tracer (1) travels with the same velocity and direction as ground water, (2) does not interact with the aquifer solids, (3) is introduced in concentrations that are substantially different from background water in the aquifer, (4) is nontoxic, and (5) does not modify aquifer properties. The following discussion focuses on characteristics (1), (2), and (3) as related to the potential tracers listed above. None of the potential tracers are toxic in concentrations previously determined in ground water in the study area (Roger Sperka, El Paso Water Utilities-Public Service Board, written commun., 1992). The potential tracers do not measurably affect the aquifer properties of the bolson sediments.

Chloride and bromide are not appreciably affected by oxidation-reduction reactions, adsorption on mineral surfaces, or mineral precipitation that would affect their transport in ground water (Whittemore, 1988 , p. 340). Iodide is very water soluble but its transport can be retarded by sorption onto natural organic matter (Lloyd and others, 1982, p. 250; Davis and others, 1985, p. 96). Potential sources of chloride, bromide, and iodide to ground water near the HBRP area include injected water, leaching of soluble chlorideand bromide-containing minerals by infiltration of irrigation water, and water from the saline zone of the aquifer.

Nitrate is a possible tracer in oxidizing ground water because of its stable anionic form and its lack of solubility and sorptive constraints (Freeze and Cherry, 1979 , p. 413). Reduction of nitrate by denitrifying bacteria in oxygen-limited environments, however, can remove nitrate from ground water and limit its use as a tracer. Oxidizing conditions, as indicated by measurable dissolved-oxygen concentrations in ground water, must be demonstrated for nitrate to be applied as a ground-water tracer. Potential sources of nitrate to ground water near the HBRP area include injected water and leaching of fertilizers and soluble nitratecontaining minerals by the infiltration of irrigation water.

Boron has been used successfully to trace treated domestic wastewater effluent in sand and gravel aquifers that lack clay minerals (Barber, 1985). The ratio of $\delta^{11} \mathrm{~B}$ also has been proposed as a tracer of liumanaffected contamination in ground water (Bassett, 1990). Boron in domestic wastewater originates principally from the use of perborate bleach additives in detergents (Waggott, 1969). Boron is also commonly present in natural waters from the leaching of rocks, minerals, and soils. Boron principally is present in natural waters with $\mathrm{pH}$ values less than 9.24 as a neutral ion pair $\left[\mathrm{B}(\mathrm{OH})_{3}\right]$ (Bassett, 1976). The transport of boron, however, can be retarded by irreversible adsorption onto montmorillonite clays like those in Hueco bolson sediments (Garza and others, 1980). The $\delta^{11} \mathrm{~B}$ values of boron also may vary because boron-10 is preferentially adsorbed onto clay minerals relative to boron-11 (Palmer and others, 1987).

The stable-isotopic ratios of $\delta^{18} \mathrm{O}$ and $\delta \mathrm{D}$ are potential tracers of ground-water flow and mixing because they are present in the water molecule itself. 


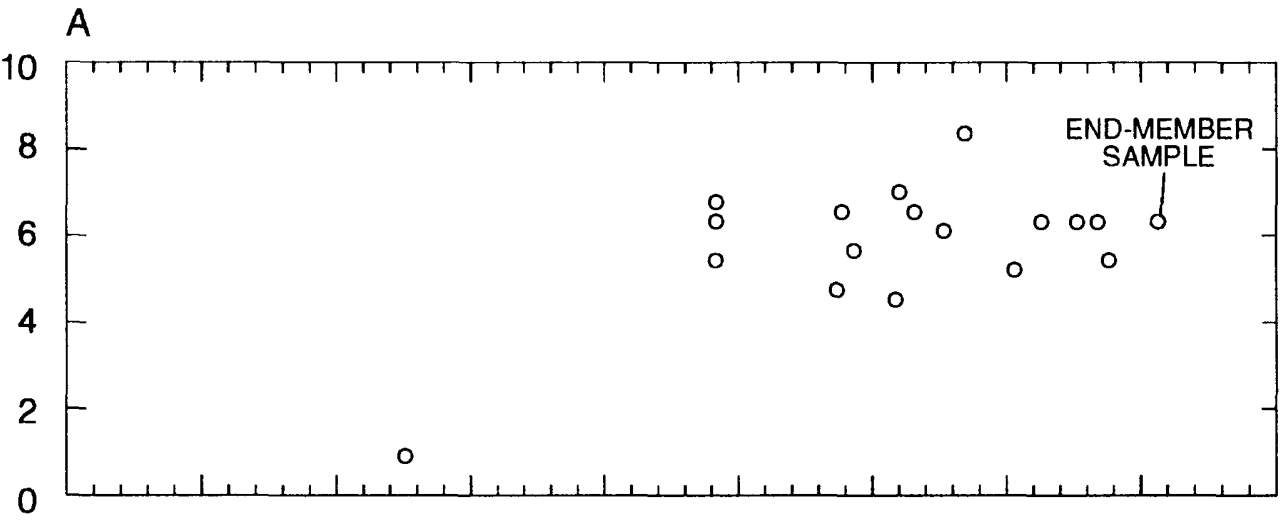

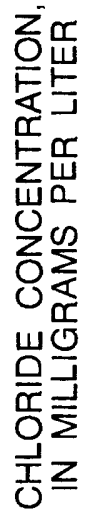

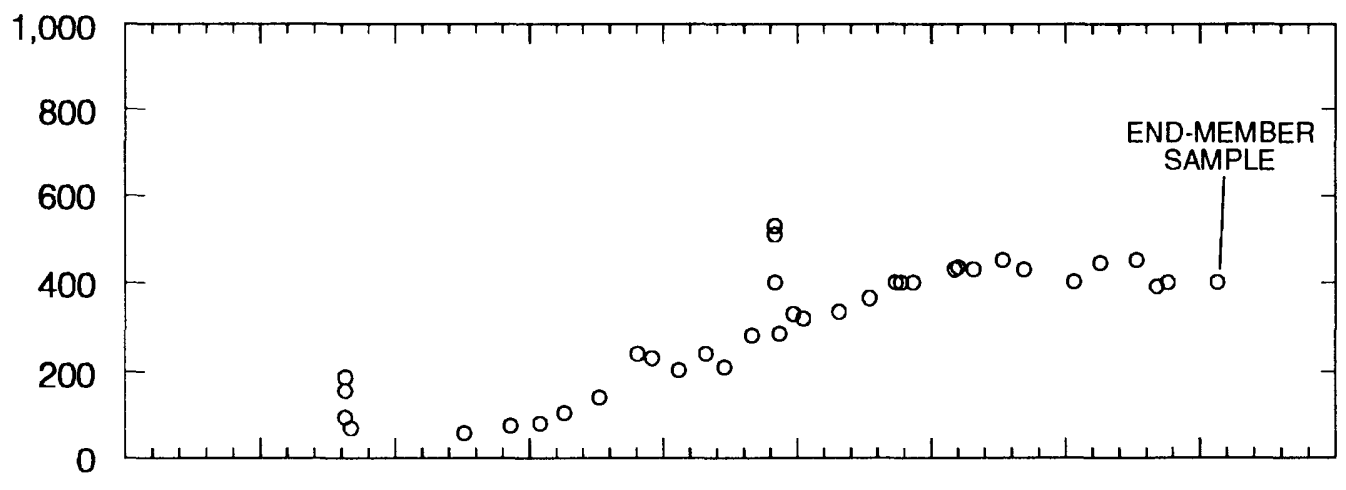

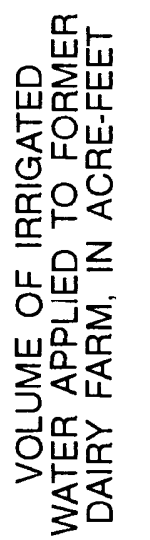

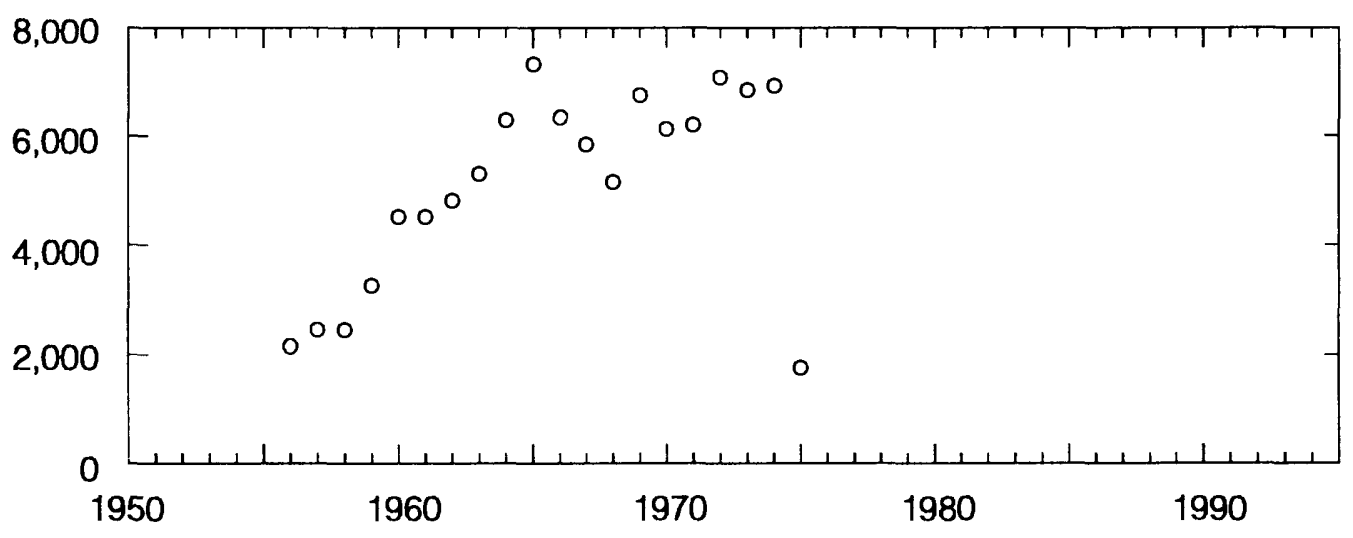

Figure 8. Nitrate and chloride concentrations in ground water in and near the Hueco Bolson Recharge Project area, EI Paso, Texas, for (A) irrigation-affected water from well 5-602 and irrigation-water volumes applied to a former dairy farm, and (B) saline water from well 5-303. 

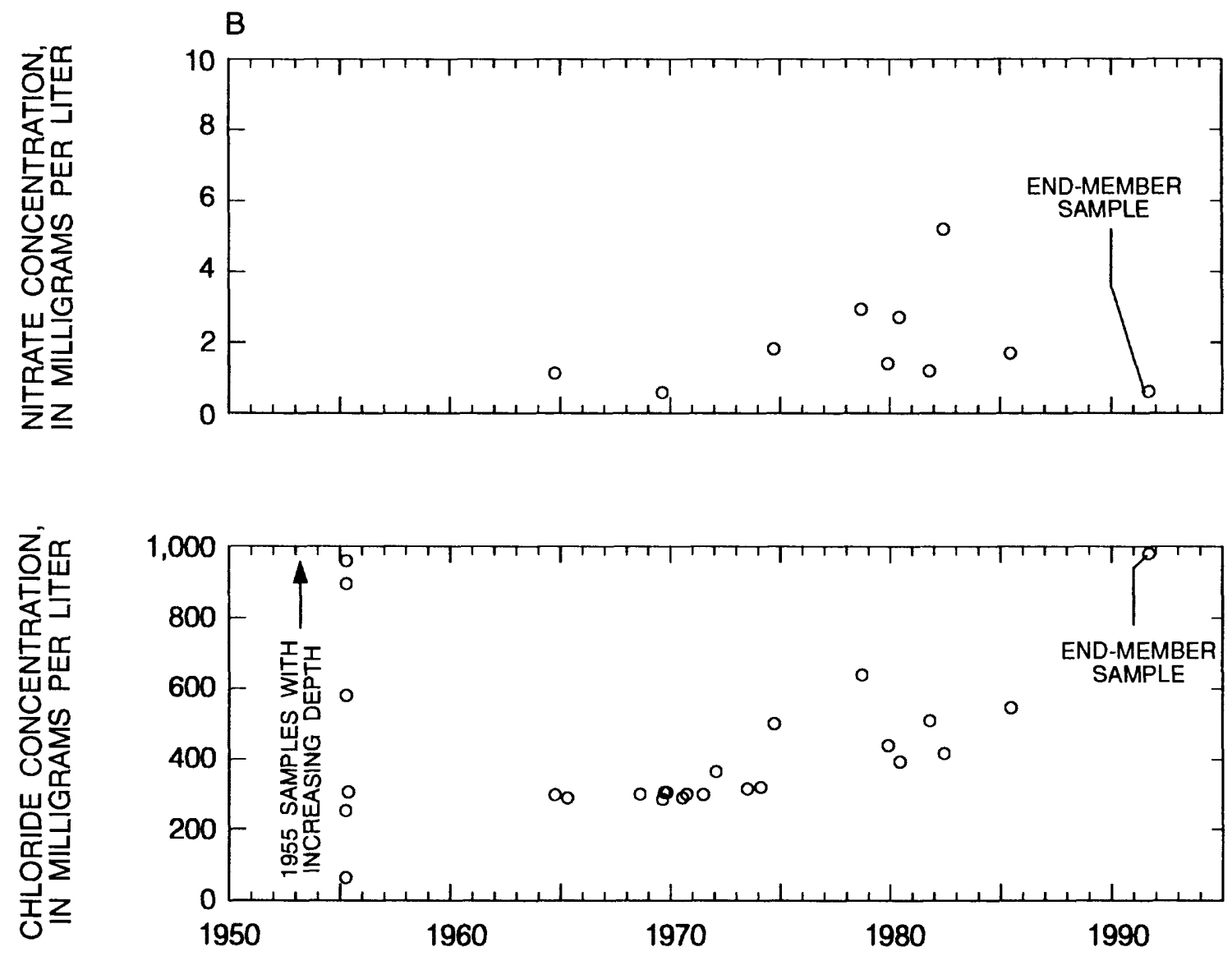

As such they are ideal tracers of the different sources of recharge and the evaporative, mixing, or reactive history of the water during ground-water flow (Fontes, 1980). Residual waters become enriched in $\delta^{18} \mathrm{O}$ and $\delta \mathrm{D}$ whenever water evaporates or mixes with an isotopically heavier water (Davis and others, 1985, p. 130131). Stable oxygen and hydrogen isotopes can be useful in identifying the residual water from evaporation because their $\delta^{18} \mathrm{O}$ and $\delta \mathrm{D}$ values are isotopically heavier than those of nomal precipitation. Wastewater may be evaporated during oxidation-pond storage before treatment and from open reactor tanks during treatment. Irrigation water probably was modified by evapotranspiration from flooded areas during its appli- cation and by crop consumptive use at the former dairy farm.

Mixing diagrams for chloride, nitrate, boron, and $\delta^{18} \mathrm{O}$ support the definition of four end members as contributors to the chemistry of ground water at the HBRP (figs. 9-11). Chemical analyses of potential tracers and other constituents in water samples are summarized by end-member category and distance from the injection wells in table 2 . Bromide and iodide concentrations and $\delta D$ values either provided similar information to chloride or $\delta^{18} \mathrm{O}$ data, or did not differ among three of the four end members (table 2). Therefore, bromide and iodide concentrations and $\delta \mathrm{D}$ values were not used in the EMMA calculation. 

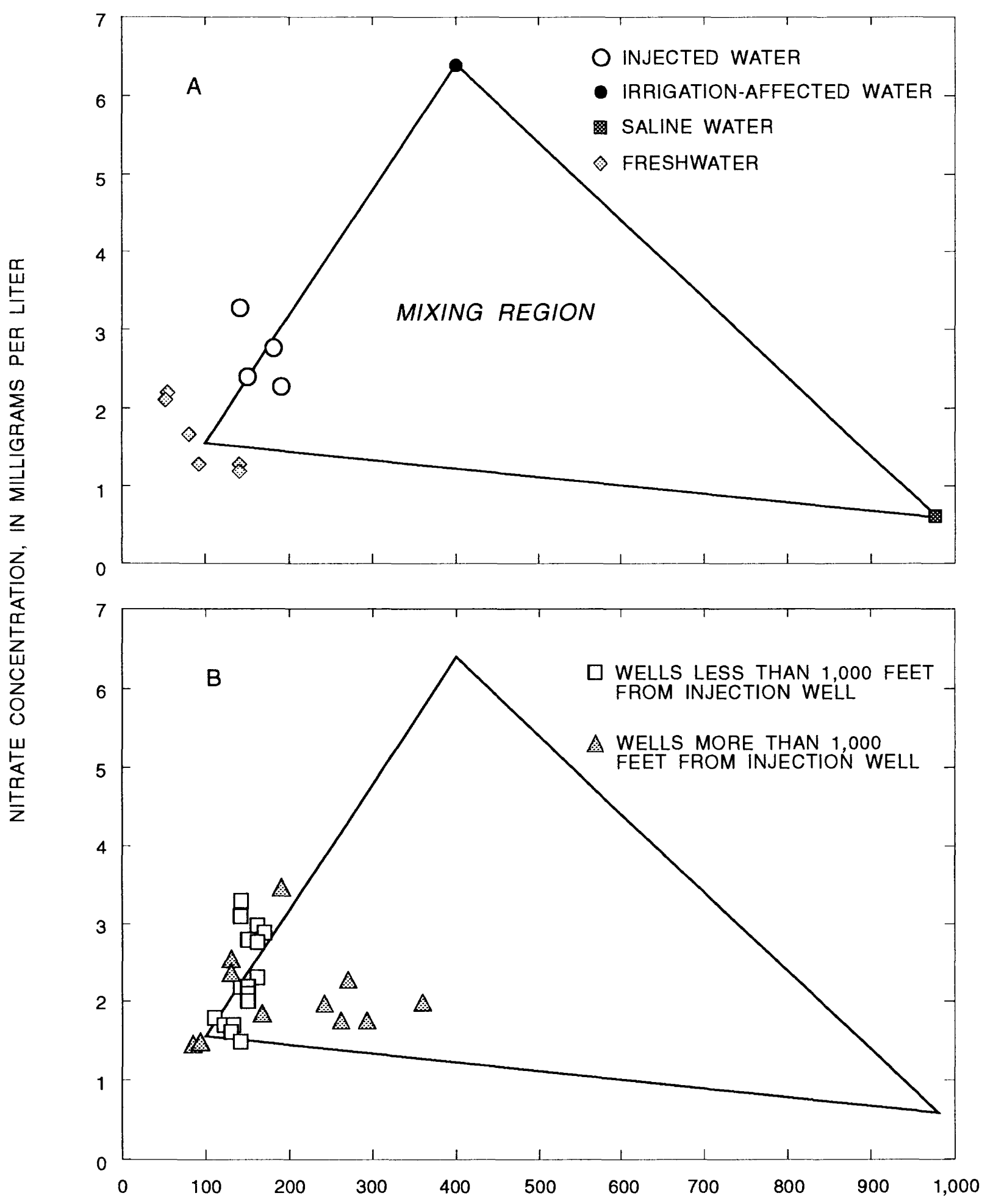

CHLORIDE CONCENTRATION, IN MILLIGRAMS PER LITER

Figure 9. Mixing diagrams showing the chemistry of water samples from wells in and near the Hueco Bolson Recharge Project area, El Paso, Texas, for (A) end members, and (B) ground-water samples with respect to potential tracers of injected water for nitrate and chloride concentrations. 


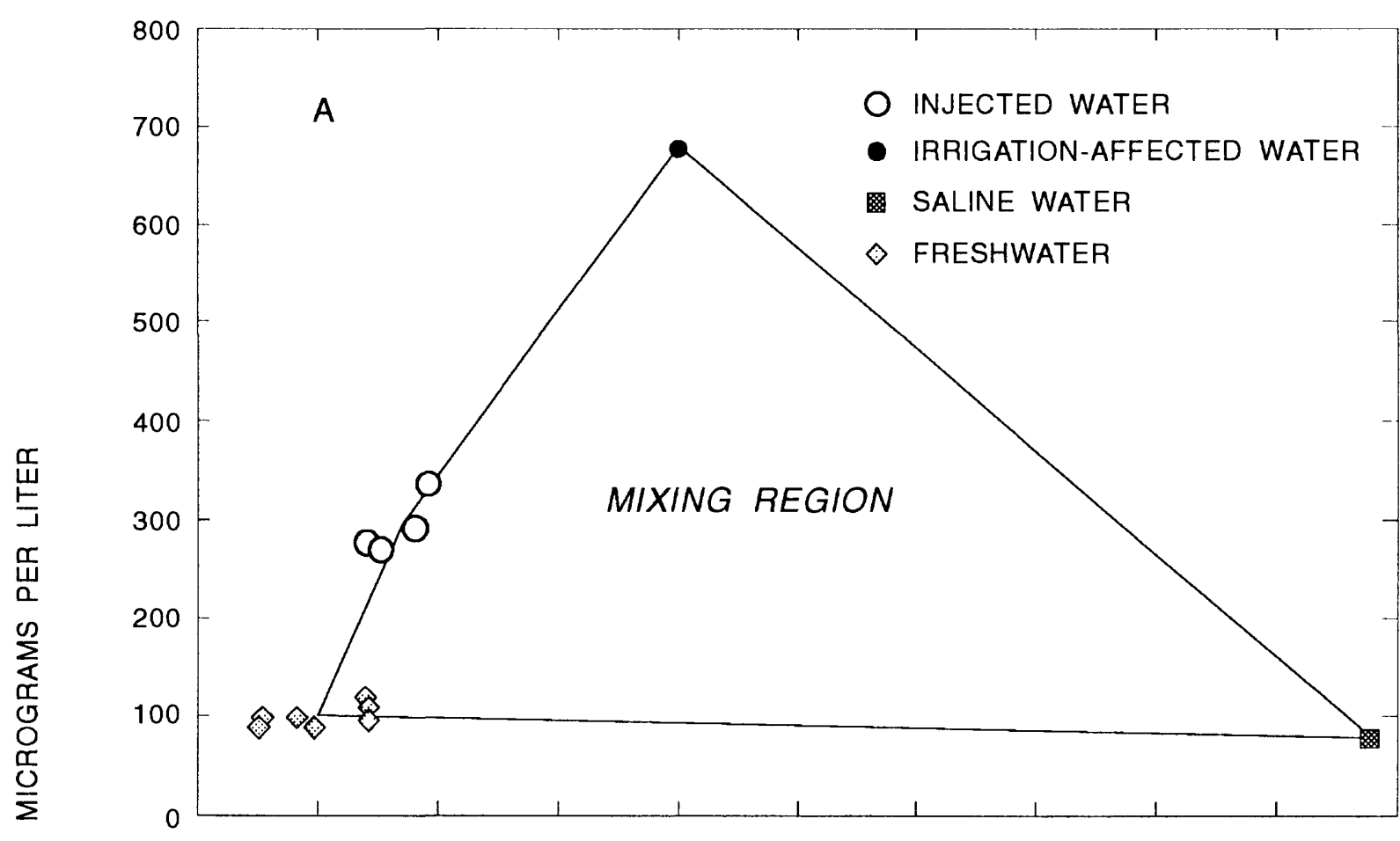

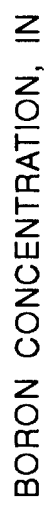

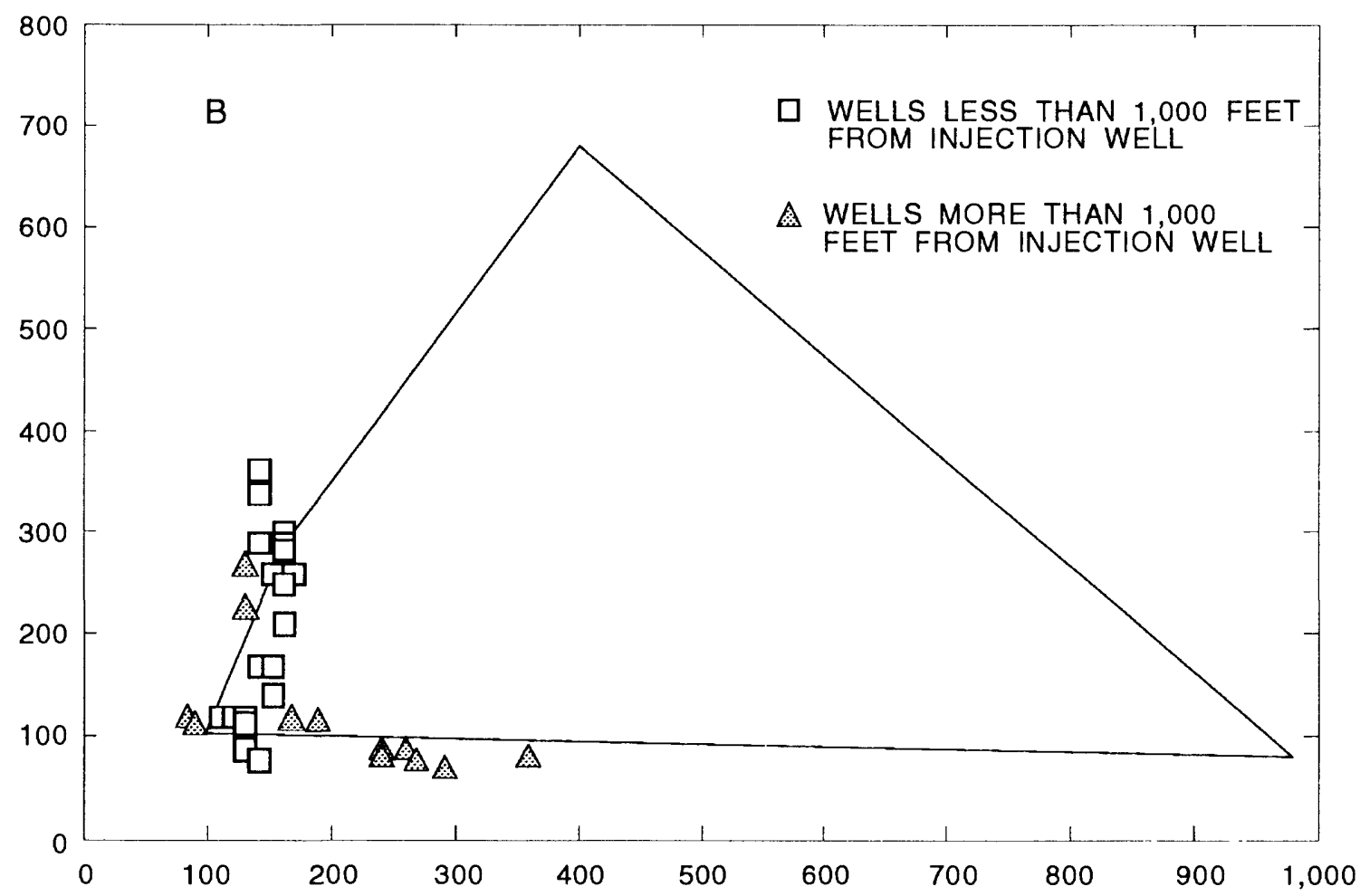

CHLORIDE CONCENTRATION, IN MILLIGRAMS PER LITER

Figure 10. Mixing diagrams showing the chemistry of water samples from wells in and near the Hueco Bolson Recharge Project area, EI Paso, Texas, for (A) end members, and (B) ground-water samples with respect to potential tracers of injected water for boron and chloride concentrations. 


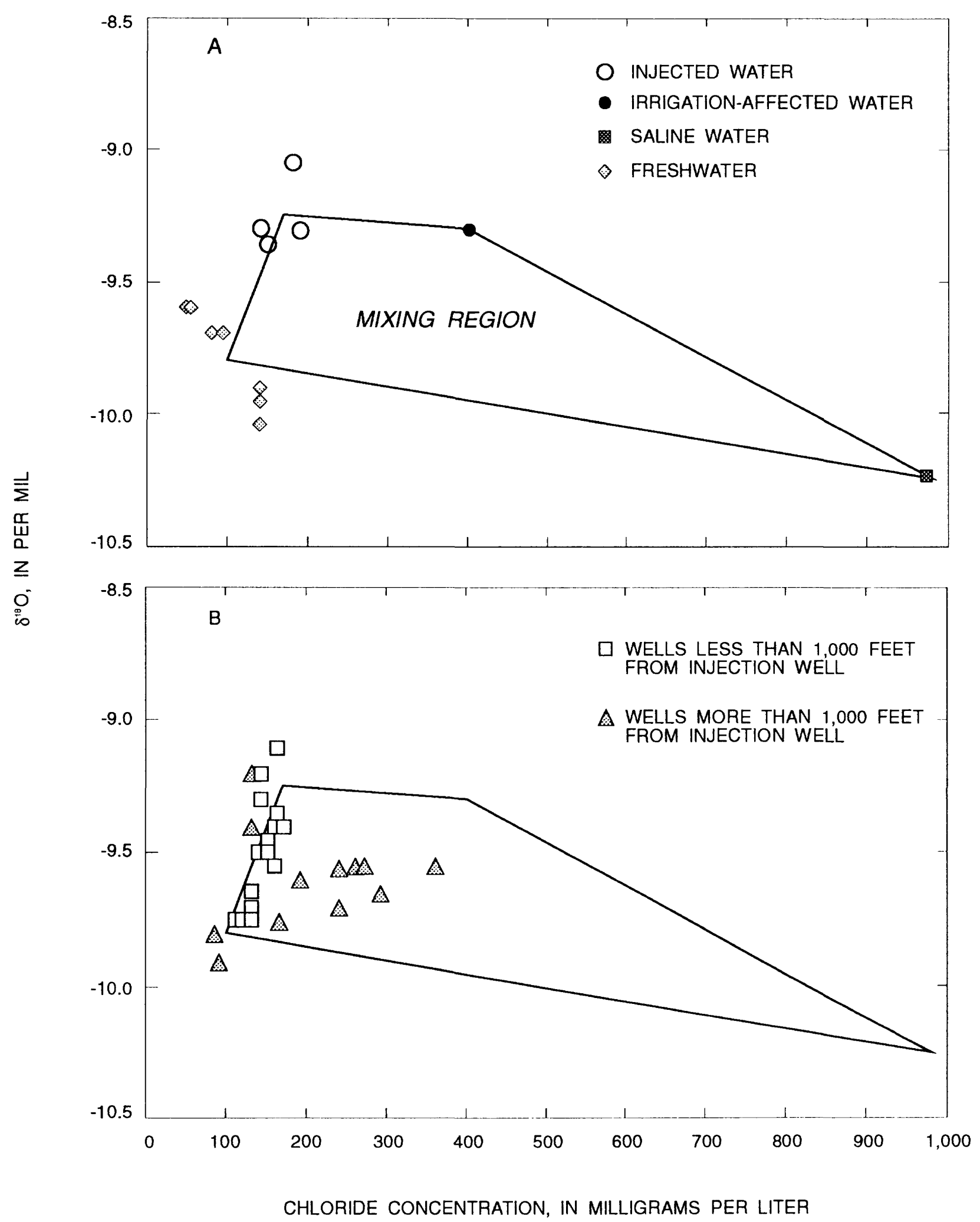

Figure 11. Mixing diagrams showing the chemistry of water samples from wells in and near the Hueco Bolson Recharge Project area, EI Paso, Texas, for (A) end members, and (B) ground-water samples with respect to potential tracers of injected water for $\delta^{18} \mathrm{O}$ values and chloride concentrations. 
Differences among the end members using chloride, nitrate, horon, $\delta^{18} \mathrm{O}$, and $\delta^{11} \mathrm{~B}$ values are shown in figures 9 to 13. The chemistry of the end members was defined using a combination of chloride and nitrate concentrations and $\delta^{18} \mathrm{O}$ values. Injected water did not have the most extreme concentrations or values of any of the potential tracers among the four end members (figs. 9-12; table 2). Irrigation-affected water from well 5-6()2 had the largest nitrate $(6.4 \mathrm{mg} / \mathrm{L}$ as $\mathrm{N})$ and boron $(680) \mu \mathrm{g} / \mathrm{L})$ concentrations of the analyzed end memhers (figs. 9, 10; table 2). Saline water had the largest chloride concentration $(980 \mathrm{mg} / \mathrm{L})$ of all the analyzed end members (table 2). Saline water from well 5-303 had the smallest nitrate $(0.6 \mathrm{mg} / \mathrm{L}$ as $\mathrm{N})$ and horon $(80) \mu \mathrm{g} / \mathrm{L})$ concentrations and the smallest $\delta^{18} \mathrm{O}$ value (-10.25 per mil) of all end members (figs. 9-11; table 2). Freshwater had the smallest chloride concentration of all end members (fig. 10).

The $\delta^{18} \mathrm{O}$ and $\delta \mathrm{D}$ values for all end members are isotopically heavier than those of meteoric water; thus they fall to the right of the regional meteoric-water line on a plot of $\delta \mathrm{D}$ versus $\delta^{18} \mathrm{O}$ (fig. 12). The regional meteoric-water line on the $\delta \mathrm{D}$ versus $\delta^{18} \mathrm{O}$ plot is defined by values that are typical of regional precipitation from Pacific Ocean air masses (Hoy and Gross, 1982, p. 67). The saline-water sample is isotopically lighter than all other water samples collected during this study. These data indicate that the stable-isotopic content of ground water has been slightly modified by cvaporation and not by mixing of ground water with an isotopically heavier brine.

Water-quality and microhial data indicate that oxidizing conditions predominate in ground water at the HBRP, and thus, nitrate concentrations are suitable for end-member definition. Dissolved-oxygen concentrations in ground water ranged from $0.7 \mathrm{mg} / \mathrm{L}$ at well $5-30.3$ to $6.3 \mathrm{mg} / \mathrm{L}$ in injected water from the wellhead of well 5-61.3 (table 2). Aerobic bacteria composed about 74 percent of the microbial population at observation well 6-405 and more than 99 percent of the microbial population at the nine other wells sampled (Brock and others, 1994). In addition, nitrogen isotopic ratios of water from local wells (table 3 ) are typical of nitrate that is predominantly derived from soil nitrogen with no apparent reduction by denitrification reactions (Kreitler and Jones, 1975). The $\delta^{15} \mathrm{~N}$ ratio ranged from 3.2 at well 5-501 to 7.6 at well 5-204 (table 3) in samples collected by the USGS in 1988.

Boron concentrations and $\delta^{11} \mathrm{~B}$ values indicated differences among the injected water, irrigation- affected water, and freshwater end members (fig. 13A). The $\delta^{11} \mathrm{~B}$ values of injected water ranged from 6.0 to 10.6 per mil (fig. 13A; table 2). These values generally were greater than those from boron in the mineral borax from Searles Lake, California ( -0.9 to 6.5 per mil; Bassett, 1990, p. 544). Borax from Searles Lake is a major source of the boron in many detergents (Dr. Randy Bassett, University of Arizona, oral commun., 1993). These data indicate that boron in the injected water originated from a mixture of natural and detergent-related sources. The $\delta^{11} \mathrm{~B}$ values for irrigationaffected water is among the largest determined for natural water (Bassett, 1990, p. 544). The mixing region defined by the $\delta^{11} \mathrm{~B}$ and boron concentrations of end members is nonlinear because $\delta^{11} \mathrm{~B}$ is a ratio, not a concentration (see per mil definition in "Conversion Factors"), and the boron concentrations of the end members differ (fig. 13A). This nonlinearity rules out use of $\delta^{11} \mathrm{~B}$ values in the linearly-based EMMA method.

Among the potential tracers of injected water, chloride, nitrate, and $\delta^{18} \mathrm{O}$ have the fewest potential geochemical limitations to their use. Although boron concentrations also indicate differences among the four end memhers, the potential for sorptive retardation of boron cannot be discounted easily. Chloride, nitrate, and $\delta^{18} \mathrm{O}$ therefore were used for the EMMA method.

\section{Distribution of Injected Water and Other End Members in Ground Water}

EMMA-predicted concentrations of solute tracers closely agree with the observed analytical data from ground-water samples (fig. 14). The agreement is critical to the accuracy of EMMA-calculated contributions of end members to the chemistry of ground-water samples (Christopherson and others, 1990).

The EMMA method results indicate that injected water has reached one production well (5-605) south of and two production wells (5-601 and 6-402) north of the injection wells as of the 1991 sampling (fig. 15; tahle 4). These results indicate that the residence time of injected water in the aquifer may be less than the 6 years estimated by Knorr and Cliett (1985). Tracers of injected water were not present or had not reached detectable concentrations in samples from the most permeahle parts of the aquifer (wells 5-603 and 5-604) as of the 1990 and 1991 samplings. 


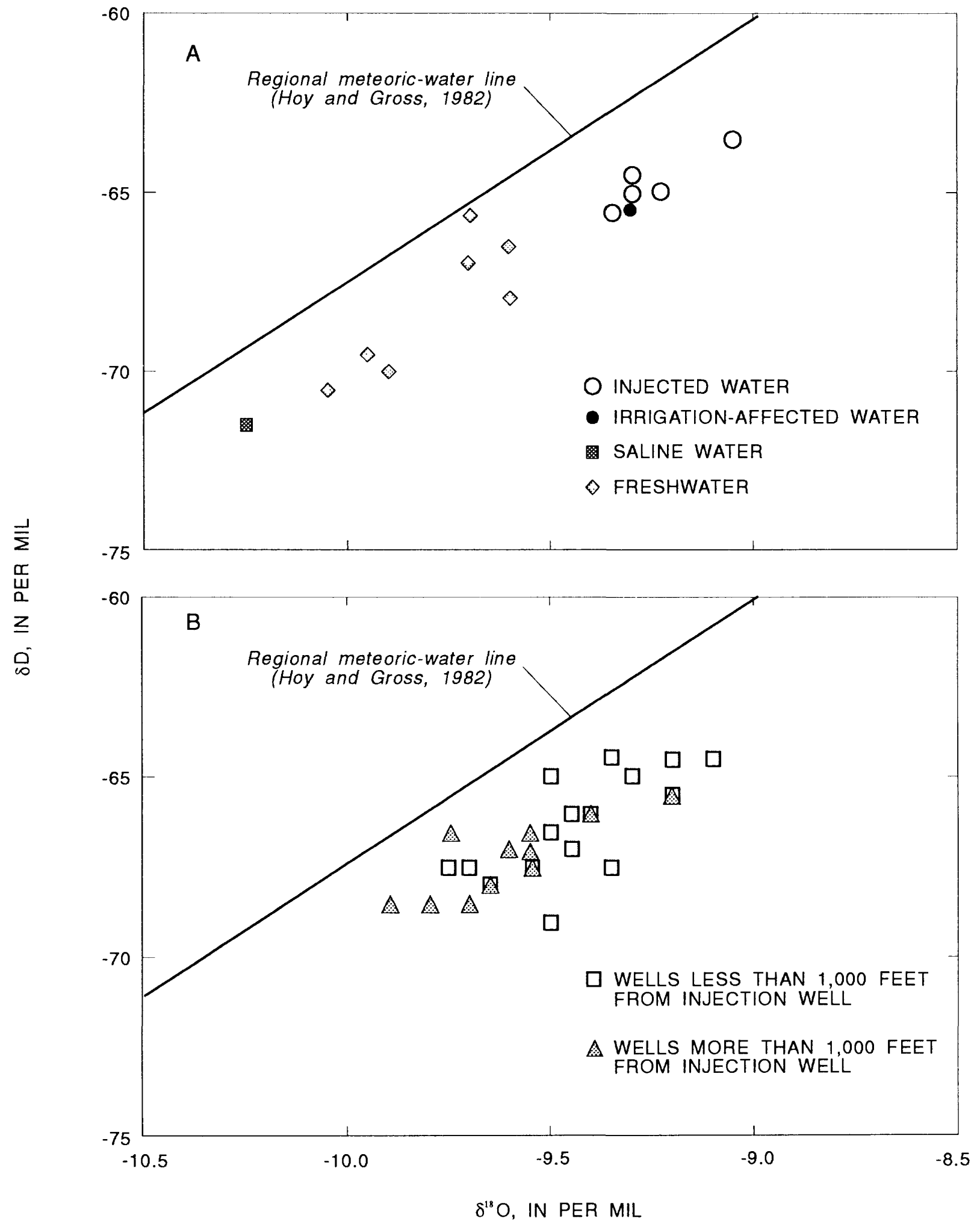

Figure 12. Mixing diagrams showing the chemistry of water samples from wells in and near the Hueco Bolson Recharge Project area, EI Paso, Texas, for (A) end members, and (B) ground-water samples with respect to potential tracers of injected water for $\delta \mathrm{D}$ and $\delta^{18} \mathrm{O}$ values. 


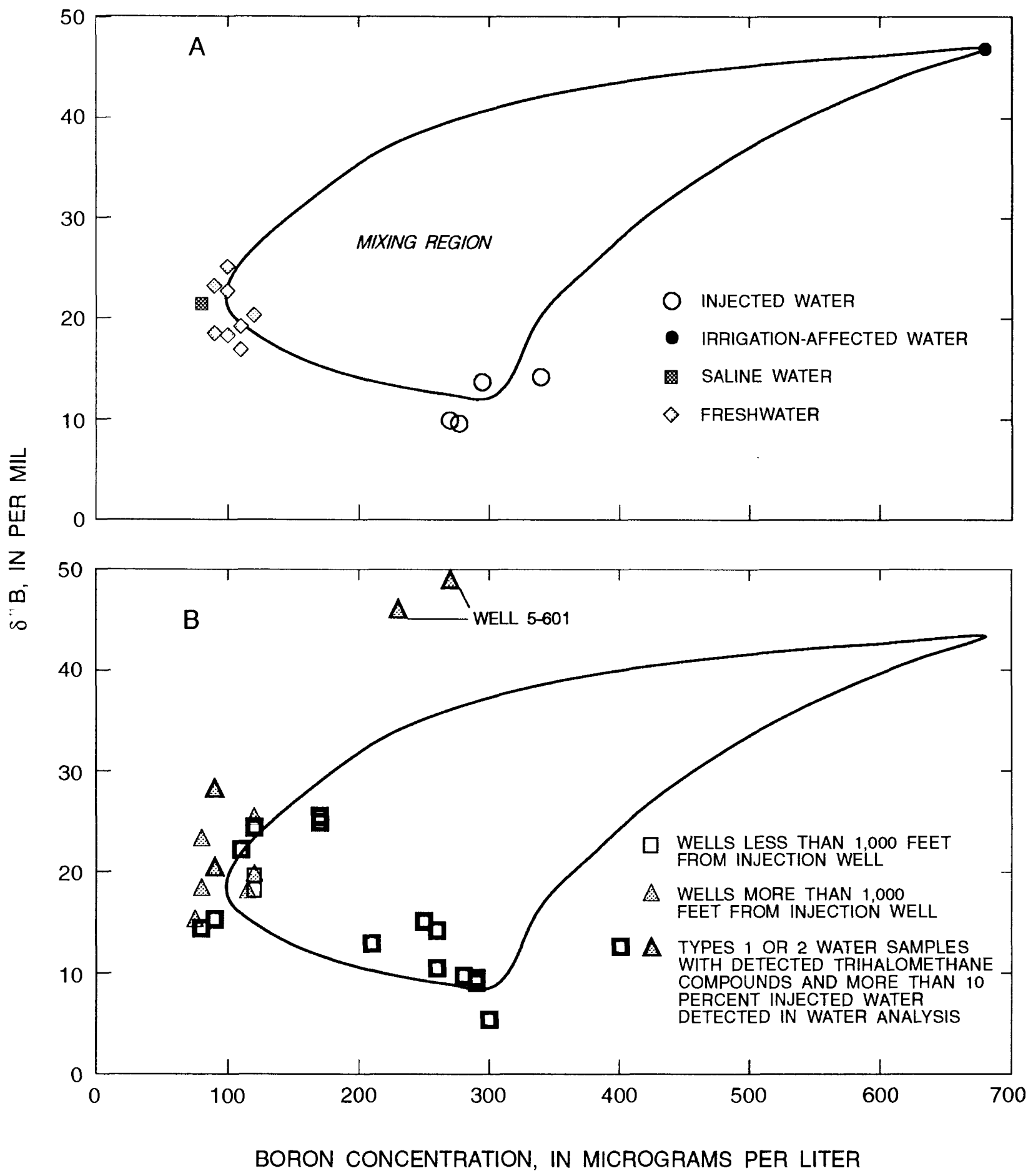

Figure 13. Mixing diagrams showing the chemistry of water samples from wells in and near the Hueco Bolson Recharge Project area, EI Paso, Texas, for (A) end members, and (B) ground-water samples with respect to potential tracers of injected water for $\delta^{11} \mathrm{~B}$ values and boron concentrations. 

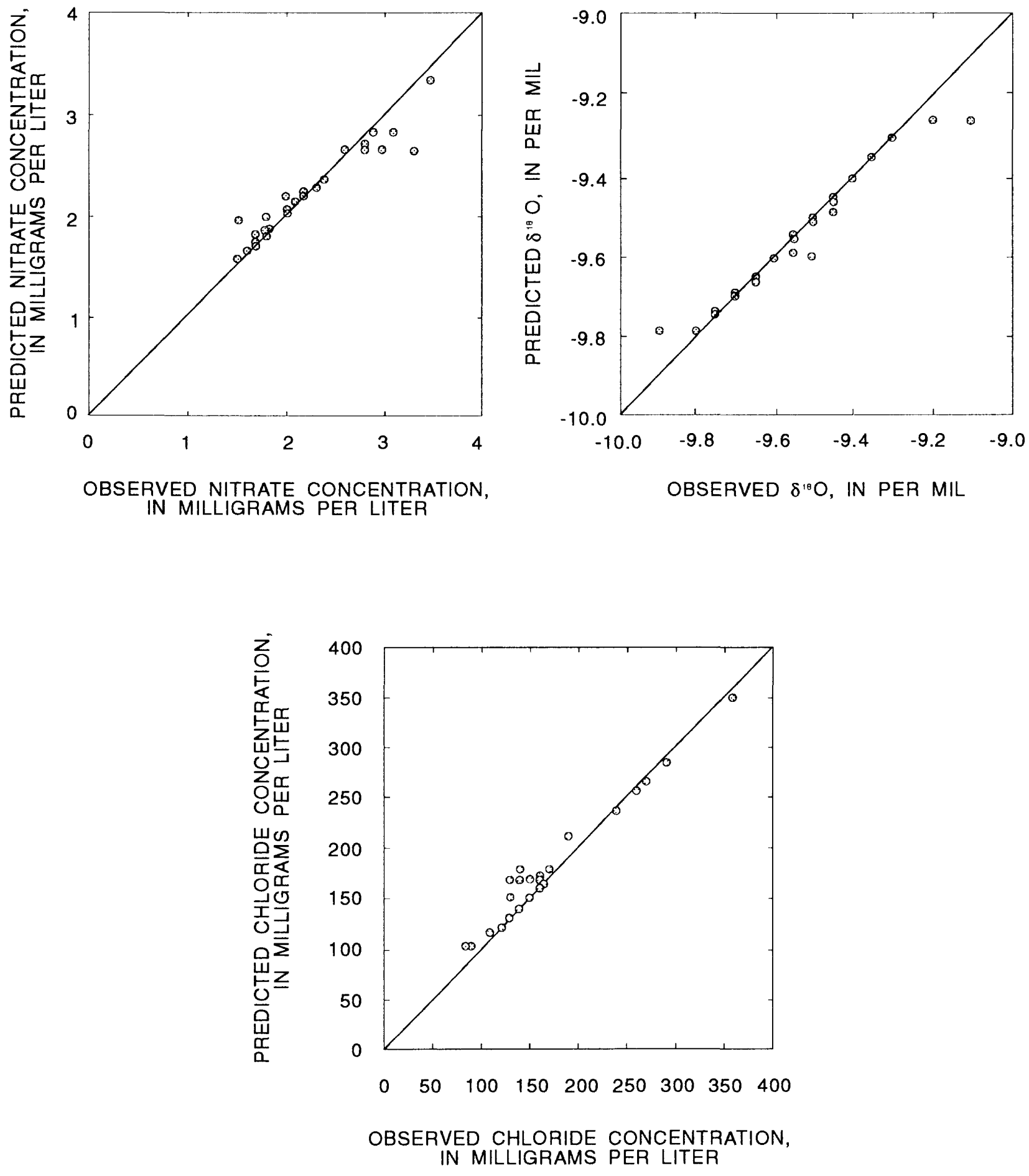

Figure 14. Observed and predicted concentrations from end-member mixing analysis for tracer constituents in water samples from wells in and near the Hueco Bolson Recharge Project area, El Paso, Texas. 

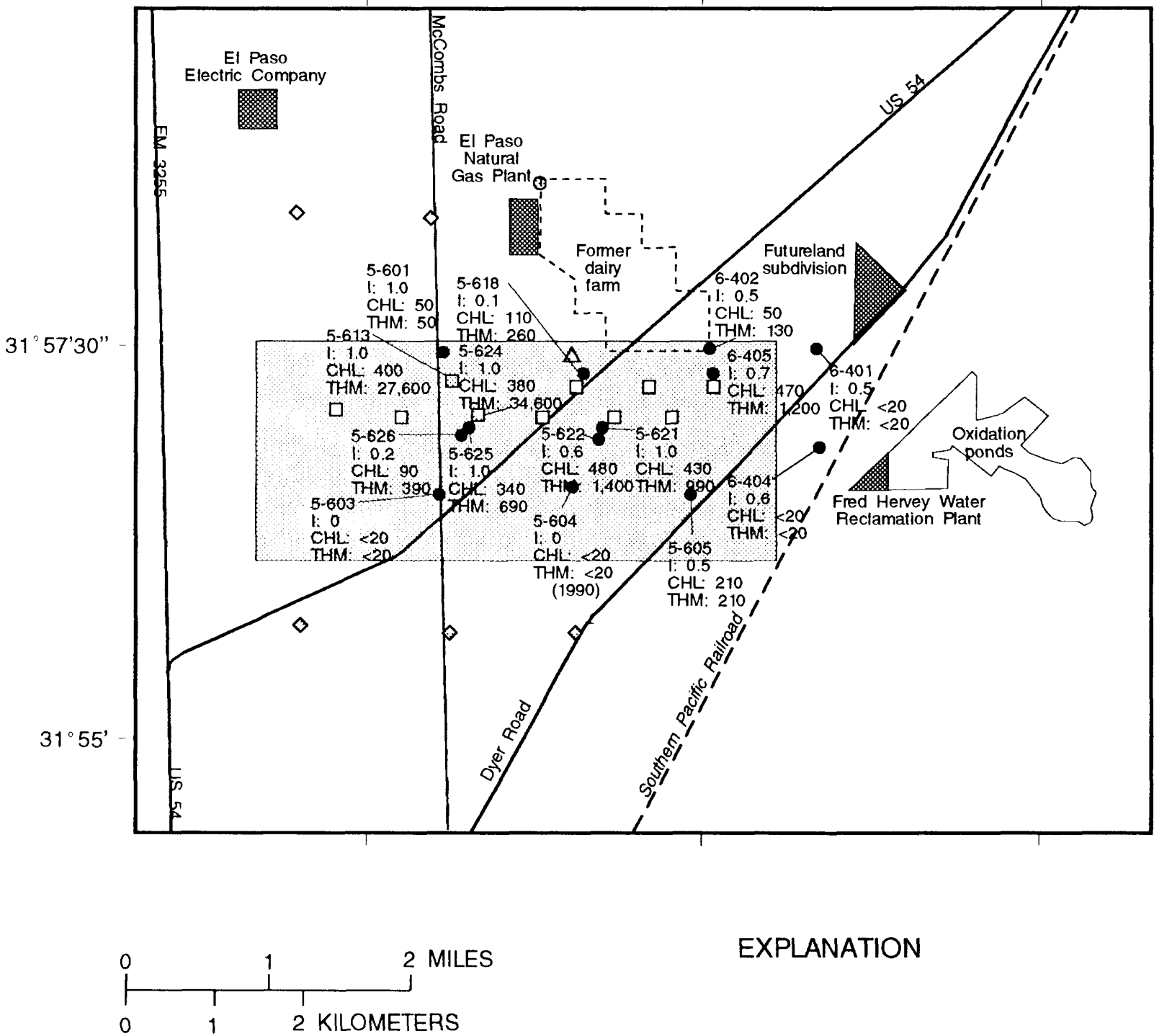

EXPLANATION

\section{HUECO BOLSON RECHARGE PROJECT AREA}

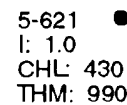

SAMPLED WELL AND NUMBER -- Values represent:

1. fraction of injected water, $\mathrm{CHL}$, chloroform concentration,

in nanograms per liter; THM, total concentration of

trihalomethane compounds, in nanograms per liter.

Values from 1991, except as noted.

\section{INJECTION WEU}

\section{WELL USED FOR END-MEMBER DEFINITION}

$\begin{array}{ll}\triangle & \text { Injected water } \\ \Delta & \text { Irrigation-affected water } \\ 0 & \text { Saline water } \\ 0 & \text { Freshwater }\end{array}$

Figure 15. Distribution of fractions of injected water and concentrations of chloroform and trihalomethane compounds in water samples. 
Table 3. Sampling information, ratios of nitrogen isotopes $\left(\delta^{15} \mathrm{~N}\right)$, and concentrations of nutrients in water from selected wells in and near the Hueco Bolson Recharge Project area, 1988-91

[N, nitrogen; $\mathrm{mg} / \mathrm{L}$, milligrams per liter; $\mathrm{P}$, phosphorus; $\mathrm{P}>24$, well pumped more than 24 hours; $<$, less than; --, no data; $\mathrm{P}<5$, well pumped less than 5 hours]

\begin{tabular}{|c|c|c|c|c|c|c|}
\hline $\begin{array}{c}\text { Well } \\
\text { number }\end{array}$ & $\begin{array}{c}\text { Date } \\
\text { sampled }\end{array}$ & $\begin{array}{l}\text { Pumping } \\
\text { time before } \\
\text { sample } \\
\text { collection }\end{array}$ & $\begin{array}{c}\delta^{15} \mathrm{~N} \text { ratio } \\
\text { (per mil) }\end{array}$ & $\begin{array}{l}\text { Nitrite plus } \\
\text { nitrate, } \\
\text { total as } \mathrm{N}^{2} \\
(\mathrm{mg} / \mathrm{L})\end{array}$ & $\begin{array}{c}\text { Nitrogen, ammonia }+ \\
\text { organic, dissolved as } \\
\mathrm{N} \text {, one determination }{ }^{2} \\
(\mathrm{mg} / \mathrm{L})\end{array}$ & $\begin{array}{c}\text { Phosphorus, } \\
\text { total as } \mathrm{P}^{2} \\
\text { (mg/L) }\end{array}$ \\
\hline $5-204$ & $\begin{array}{l}05 / 23 / 88 \\
08 / 30 / 90 \\
08 / 23 / 91\end{array}$ & $\begin{array}{l}P>24 \\
P>24 \\
P>24\end{array}$ & $\begin{array}{l}7.6 \\
-- \\
--\end{array}$ & $\begin{array}{l}1.2 \\
1.2 \\
1.2\end{array}$ & $\begin{array}{r}0.3 \\
<.2 \\
<.2\end{array}$ & $\begin{array}{l}<0.01 \\
<.01 \\
<.01\end{array}$ \\
\hline $5-501$ & $\begin{array}{l}05 / 23 / 88 \\
08 / 23 / 90\end{array}$ & $\begin{array}{l}P>24 \\
P>24\end{array}$ & $\begin{array}{l}3.2 \\
--\end{array}$ & $\begin{array}{l}1.3 \\
1.3\end{array}$ & $\begin{array}{r}.2 \\
<.2\end{array}$ & $\begin{array}{l}.01 \\
.01\end{array}$ \\
\hline $5-602$ & $\begin{array}{l}05 / 23 / 88 \\
10 / 19 / 88 \\
10 / 21 / 88\end{array}$ & $\begin{array}{l}\mathrm{P}>24 \\
\mathrm{P}<5 \\
\mathrm{P}>24\end{array}$ & $\begin{array}{l}-- \\
6.0 \\
6.3\end{array}$ & $\begin{array}{r}6.3 \\
{ }_{1} 2.6 \\
1_{4} .7\end{array}$ & $\begin{array}{l}.3 \\
-- \\
--\end{array}$ & $\begin{array}{l}.01 \\
-- \\
--\end{array}$ \\
\hline & $\begin{array}{l}08 / 22 / 90 \\
09 / 10 / 91 \\
09 / 10 / 91\end{array}$ & $\begin{array}{l}P>24 \\
P<5 \\
P<5\end{array}$ & $\begin{array}{l}-- \\
-- \\
--\end{array}$ & $\begin{array}{l}6.4 \\
1.9 \\
1.9\end{array}$ & $\begin{array}{l}.6 \\
.3 \\
.2\end{array}$ & $\begin{array}{l}<.01 \\
<.01 \\
<.01\end{array}$ \\
\hline $5-604$ & $\begin{array}{l}05 / 23 / 88 \\
08 / 22 / 90\end{array}$ & $\begin{array}{l}P>24 \\
P>24\end{array}$ & $\begin{array}{l}6.2 \\
--\end{array}$ & $\begin{array}{l}3.3 \\
3.5\end{array}$ & $\begin{array}{r}<.2 \\
.6\end{array}$ & $\begin{array}{r}.01 \\
<.01\end{array}$ \\
\hline $6-402$ & $\begin{array}{l}05 / 23 / 88 \\
09 / 01 / 90 \\
09 / 01 / 90\end{array}$ & $\begin{array}{l}P>24 \\
P>24 \\
P>24\end{array}$ & $\begin{array}{l}5.5 \\
-- \\
--\end{array}$ & $\begin{array}{l}1.8 \\
1.8 \\
1.8\end{array}$ & $\begin{array}{l}.2 \\
.2 \\
.4\end{array}$ & $\begin{array}{r}.01 \\
.03 \\
<.01\end{array}$ \\
\hline & $\begin{array}{l}08 / 24 / 91 \\
08 / 24 / 91 \\
08 / 24 / 91\end{array}$ & $\begin{array}{l}P>24 \\
P>24 \\
P>24\end{array}$ & $\begin{array}{l}-- \\
-- \\
--\end{array}$ & $\begin{array}{l}1.8 \\
1.8 \\
1.8\end{array}$ & $\begin{array}{r}.3 \\
<.2 \\
<.2\end{array}$ & $\begin{array}{r}.01 \\
<<.01 \\
<.01\end{array}$ \\
\hline
\end{tabular}

1 Analysis performed by Global Geochemistry Corp., Canoga Park, Calif.

${ }^{2}$ Analysis performed by U.S. Geological Survey except as .ıoted.

Water samples that contained injected-water tracers were grouped into three categories, or water types, according to their total concentrations of THM compounds. These 3 water types are: (1) those with total THM compound concentrations greater than 500 $\mathrm{ng} / \mathrm{L}$, (2) those with total THM compound concentrations ranging from 20 to $500 \mathrm{ng} / \mathrm{L}$, and (3) those with no detectable THM compounds (fig. 15; table 4). A concentration of THM compounds less than the detection limit of $20 \mathrm{ng} / \mathrm{L}(<20 \mathrm{ng} / \mathrm{L})$ indicated that no detectable concentrations of THM compounds were in the water sample. Water samples of type (1) are from wells 5-621, 5-622, 5-625, and 6-405 that are within $700 \mathrm{ft}$ of an injection well (fig. 16A-C; table 4). A 1.0 fraction of injected water was calculated for type
(1) water samples from wells 5-621 (430) and $640 \mathrm{ft}$ depth of samples) and 5-625 (4.30 and 605 ft depth of samples) using 1991 data (table 4). Water samples of type (2) are from observation wells 5-618 and 5-626 and production wells 5-60)1, 5-605, and 6-4()2 (figs. 15 and $16 \mathrm{~A}-\mathrm{C}$; table 4). Observation well 5-618 is about $300 \mathrm{ft}$ from the nearest injection well, 5-619 (fig. 2). The remaining wells with type (2) water samples range from about 1,170 to $2,900 \mathrm{ft}$ away from the nearest injection wells. Water samples of type (3) are from wells 6-401 and 6-404.

The distribution of types (1) and (2) water samples relative to their concentrations of boron and $\delta^{11} \mathrm{~B}$ values indicate that boron concentrations or isotopes are probably not conservative indicators of the 
injected-water contribution (fig. 13B). The boron data from several types (1) and (2) water samples coincide with samples that define the freshwater end member. Sorption-related changes in concentrations of boron and its stable isotopes would explain the retardation of boron migration in ground water relative to the injected-water tracers. Changes in the source concentrations of boron and its stable isotopes since reclaimed-water injection commenced also would explain the differences in these distributions. The principal sources of wastewater to the plant remain primarily from domestic and commercial wastewater, making it likely that the source concentrations of boron have not changed appreciably since 1985 .

The apparent breakthrough velocity of injectedwater tracers through the entire screened depth of the aquifer was estimated for water samples with fractions of injected-water tracers that ranged from greater than 0.4 to less than 0.6 and with detectable concentrations of THM compounds. "Breakthrough" is defined as the time required for half the original concentrations or values of injected-water tracers to reach a well. Wells with a water sample meeting breakthrough conditions included 5-605, 5-622, 5-625, 6-402, and 6-405 (table 4). When a water sample reflected a breakthrough of injected-water tracers between sampling events (well 6-405), a range of apparent breakthrough velocities was calculated. When a water sample reflected a breakthrough of injected-water tracers before the study (well 5-601), a minimum apparent breakthrough velocity was indicated by a greater-than sign preceding the value in table 5 . The calculation of apparent breakthrough velocity was made as follows (Freeze and Cherry, 1979, p. 390-391):

$$
V(\operatorname{app})=\frac{x}{\left.t_{\left(c / c_{0}\right.}=0.5\right)-t_{0}}
$$

where $\mathrm{V}($ app $)=$ the apparent longitudinal breakthrough velocity, in feet per day, from the injection well to the sampled well;

$\mathrm{x}=$ the distance, in feet, from the injection well to the sampled well;

$\left.t_{\left(c / c_{0}\right.}=0.5\right)=$ the time, in days after a reference time, when the water sample with a fraction of about 0.5 injected water, was collected;

$$
\begin{gathered}
\left(\mathrm{c} / \mathrm{c}_{\mathrm{O}}=0.5\right)=\begin{array}{l}
\text { the position of the advective front at } \\
\text { breakthrough; and }
\end{array} \\
\mathrm{t}_{\mathrm{o}}=\begin{array}{c}
\text { the initial time, in days after a } \\
\text { reference time, of the start of } \\
\text { reclaimed-water injection at the } \\
\text { nearest injection well. }
\end{array}
\end{gathered}
$$

The apparent breakthrough velocities of injected water range from about $0.13 \mathrm{ft} / \mathrm{d}$ between wells 5-624 and 5-625 to about $1.3 \mathrm{ft} / \mathrm{d}$ between wells 5-616 and 5-605 (table 5). The apparent breakthrough velocity between injection well 5-624 and observation well 5-625 is less than the average linear ground-water velocity approximately between wells 5-625 and 5-603 (tables 1 and $5)$. The apparent breakthrough velocity between injection well 5-620 and observation well 5-622 is also less than the average linear ground-water velocity along a parallel line between wells 5-621 and 5-604. Dispersive mixing is the likely cause for the smaller apparent breakthrough velocities.

The average breakthrough velocity of injected water may be slower than the average linear groundwater velocities because of transverse components of dispersion and adjective transport. A substantial transverse component to dispersion would dilute injectedwater tracer concentrations more than if transport was principally in just one dimension. The result would be a decrease in the apparent, average breakthrough velocity of injected water from that predicted using a onedimensional flow equation. The complete breakthrough of injected water at wells 5-621 and 5-625 (injected-water fraction $=1.0$ ) indicates that the effect of transverse dispersion is not important near these wells. It is more likely that the effect of transverse dispersion and dilution of injected water is more important at wells 5-622 and 5-626, which are farther downgradient from the injection wells.

The results of the calculations of average breakthrough velocity should be considered "best estimates," given the limitations of well construction, HBRP operation, and nonhomogeneous, anisotropic-aquifer conditions. Water samples used for the EMMA method were collected from wells that produce from several hundred feet of aquifer and, therefore, probably represent vertically-averaged concentrations from several permeable zones. The equation used to calculate the breakthrough velocities also assumes that injection rates are relatively constant with time. However, the monthly volume of water injected at the wells closest to the observation wells (6-406, 5-616, 5-620, and 5-624) was variable during HBRP operation, ranging from 0 to 

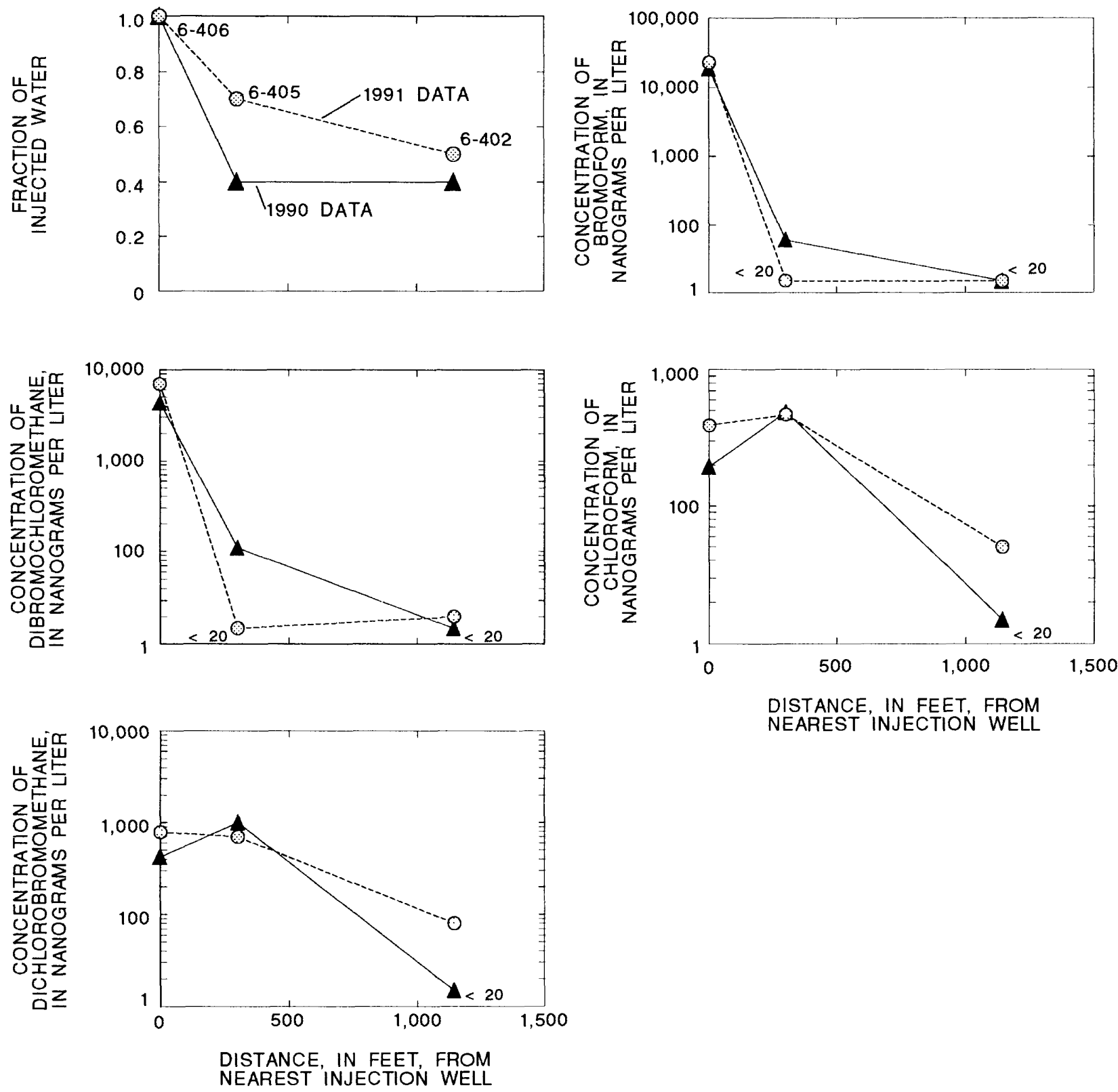

NEAREST INJECTION WELL

A. Wells 6-406, 6-405, and 6-402.

Figure 16. Graphs showing comparison of fractions of injected water with concentrations of trihalomethane compounds among samples from wells in the Hueco Bolson Recharge Project area, El Paso, Texas. 

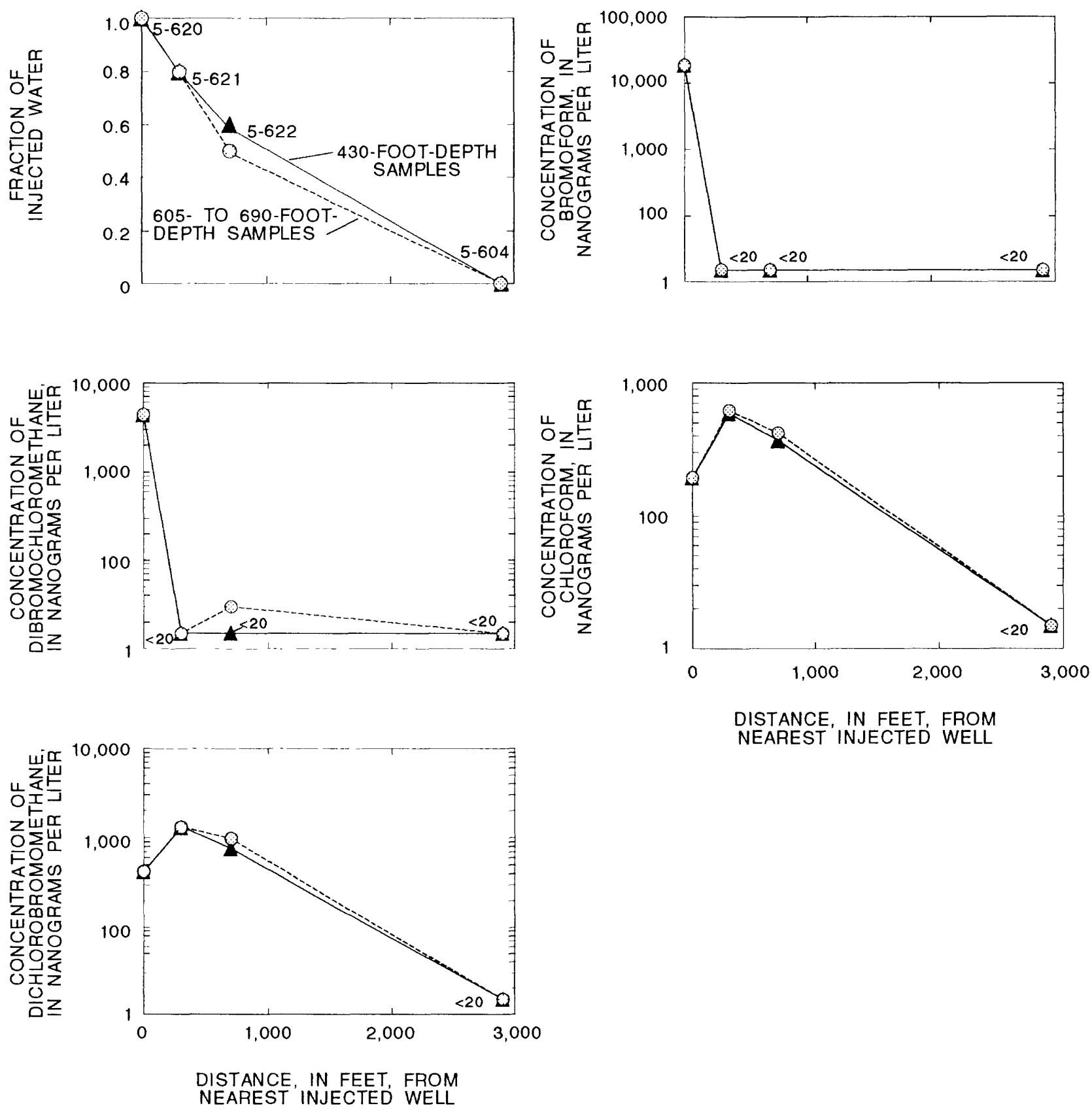

NEAREST INJECTED WELL

B. Wells 5-620, 5-621, 5-622, and 5-604. 

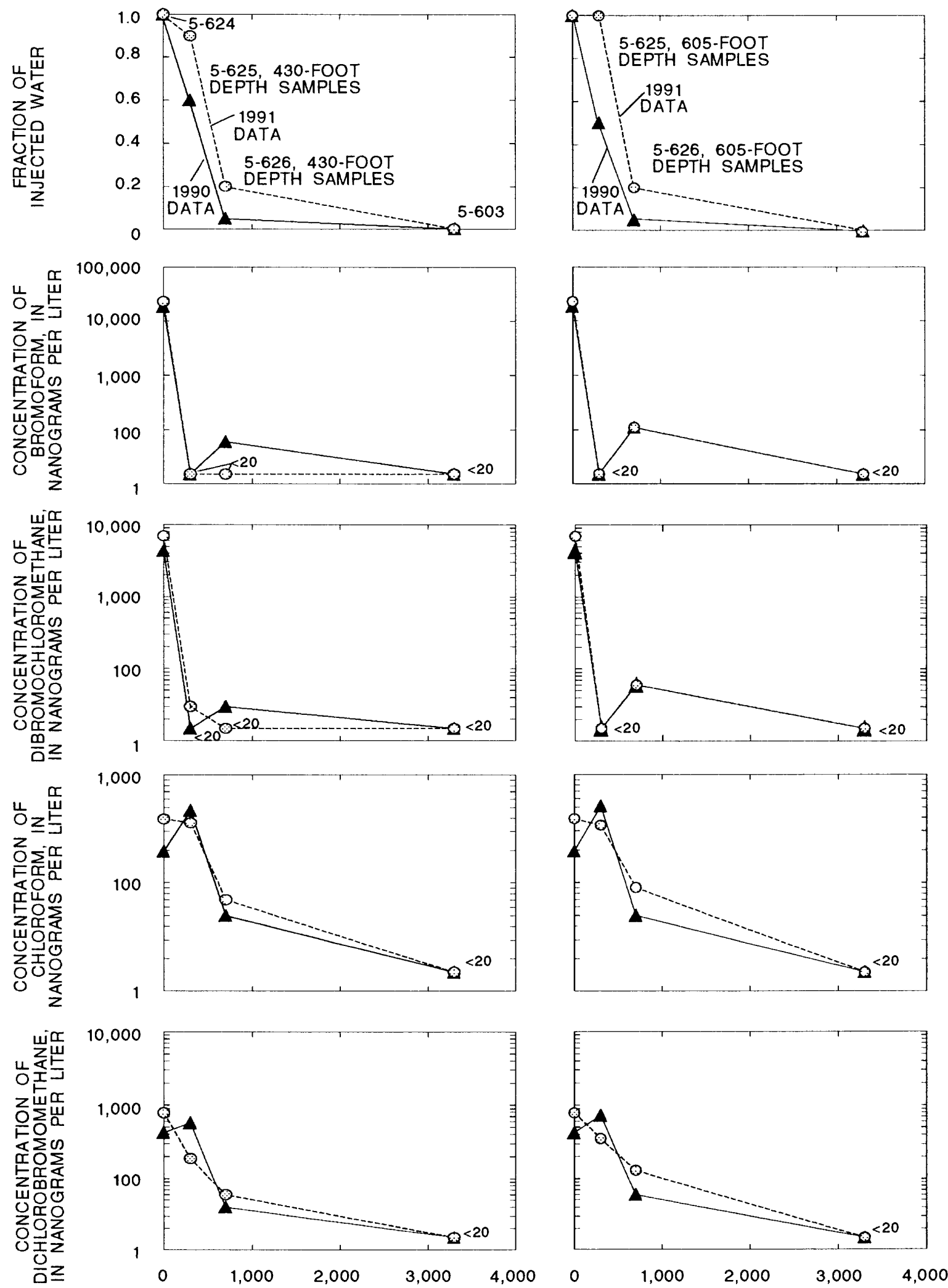

DISTANCE, IN FEET, FROM NEAREST INJECTION WELL

C. Wells 5-624, 5-625, 5-626, and 5-603.

Figure 16.--Continued.

30 Hydrogeology and Selected Water-Quality Aspects of the Hueco Bolson Aquifer at the Hueco Bolson Recharge Project Area, 
Table 4. Calculated fractions of end members contributing to ground-water chemistry in and near the Hueco Bolson Recharge Project area

[Calculated fractions for a water sample may sum to more or less than 1 because of rounding. Water type: (1) water samples with total THM compound concentrations greater than $500 \mathrm{ng} / \mathrm{L}$; (2) from 20 to $500 \mathrm{ng} / \mathrm{L} ;(3)<20 \mathrm{ng} / \mathrm{L}$ (no detectable THM compounds); THM, trihalomethane; ng/L, nanogram per liter; Trace, end-member fractional contribution less than $0.1 ;$--, injected water fraction too small to classify water type; <, less than]

\begin{tabular}{|c|c|c|c|c|c|c|c|c|}
\hline $\begin{array}{c}\text { Well } \\
\text { number }\end{array}$ & $\begin{array}{c}\text { Water } \\
\text { type }\end{array}$ & $\begin{array}{c}\text { Year } \\
\text { sampled }\end{array}$ & $\begin{array}{l}\text { Depth sampled } \\
\text { (feet below } \\
\text { land surface) }\end{array}$ & $\begin{array}{l}\text { Injected } \\
\text { water }\end{array}$ & $\begin{array}{l}\text { Irrigation- } \\
\text { affected } \\
\text { water }\end{array}$ & $\begin{array}{l}\text { Saline } \\
\text { water }\end{array}$ & Freshwater & $\begin{array}{c}\text { THM } \\
\text { (ng/L) }\end{array}$ \\
\hline \multicolumn{9}{|c|}{ Wells less than 1,000 feet from injection wells } \\
\hline \multirow[t]{2}{*}{$5-618$} & 2 & 1990 & $327-705$ & 0.4 & 0 & 0 & 0.6 & 160 \\
\hline & 2 & 1991 & $327-705$ & .1 & 0 & 0 & .9 & 260 \\
\hline \multirow[t]{4}{*}{$5-621$} & 1 & 1990 & 430 & .8 & Trace & 0 & .2 & 1,900 \\
\hline & 1 & 1990 & 640 & .8 & Trace & 0 & .2 & 1,900 \\
\hline & 1 & 1991 & 430 & 1 & 0 & 0 & 0 & 990 \\
\hline & 1 & 1991 & 640 & 1 & 0 & 0 & 0 & 960 \\
\hline \multirow[t]{4}{*}{$5-622$} & 1 & 1990 & 430 & 6 & 0 & 0 & .4 & 1,100 \\
\hline & 1 & 1990 & 690 & .5 & 0 & 0 & .5 & 1,400 \\
\hline & 1 & 1991 & 430 & .6 & 0 & 0 & .4 & 1,400 \\
\hline & 1 & 1991 & 605 & .5 & 0 & 0 & .5 & 1,400 \\
\hline \multirow[t]{4}{*}{$5-625$} & 1 & 1990 & 430 & 6 & 0.1 & 0 & .3 & 1,000 \\
\hline & 1 & 1990 & 605 & .5 & .1 & 0 & .4 & 1,200 \\
\hline & 1 & 1991 & 430 & .9 & Trace & 0 & Trace & 580 \\
\hline & 1 & 1991 & 605 & 1 & 0 & 0 & 0 & 690 \\
\hline \multirow[t]{4}{*}{$5-626$} & -- & 1990 & 430 & Trace & 0 & 0 & .9 & 180 \\
\hline & -- & 1990 & 605 & Trace & 0 & 0 & .9 & 280 \\
\hline & 2 & 1991 & 430 & .2 & 0 & 0 & .8 & 130 \\
\hline & 2 & 1991 & 605 & .2 & 0 & 0 & .8 & 390 \\
\hline \multirow[t]{2}{*}{$6-405$} & 1 & 1990 & $360-710$ & .4 & Trace & 0 & .5 & 1,700 \\
\hline & 1 & 1991 & $360-710$ & .7 & Trace & 0 & .3 & 1,200 \\
\hline \multicolumn{9}{|c|}{ Wells more than 1,000 feet from injection wells } \\
\hline \multirow[t]{2}{*}{$5-601$} & 2 & 1990 & $350-690$ & .7 & 0 & 0 & .3 & 50 \\
\hline & 2 & 1991 & $350-690$ & 1 & 0 & 0 & 0 & 50 \\
\hline \multirow[t]{2}{*}{$5-603$} & -- & 1990 & $352-657$ & 0 & 0 & 0 & 1 & $<20$ \\
\hline & -- & 1991 & $352-657$ & 0 & 0 & 0 & 1 & $<20$ \\
\hline $5-604$ & -- & 1990 & $382-802$ & 0 & .4 & 0 & .6 & $<20$ \\
\hline \multirow[t]{2}{*}{$5-605$} & 2 & 1990 & $343-769$ & .2 & Trace & 0.1 & .6 & 270 \\
\hline & 2 & 1991 & $343-769$ & .5 & 0 & .1 & .4 & 210 \\
\hline $6-401$ & 3 & 1991 & $348-451$ & .5 & Trace & .1 & .3 & $<20$ \\
\hline \multirow[t]{2}{*}{$6-402$} & 2 & 1990 & $363-670$ & .4 & 0 & .2 & .4 & $<20$ \\
\hline & 2 & 1991 & $363-670$ & .5 & () & .1 & .4 & 1.30 \\
\hline $6-404$ & 3 & 1991 & -- & .6 & 0 & .3 & .1 & $<20$ \\
\hline
\end{tabular}


Table 5. Apparent breakthrough velocity of injected water between selected wells in the Hueco Bolson Recharge Project area

[>, greater than]

\begin{tabular}{|c|c|c|c|c|c|c|}
\hline $\begin{array}{l}\text { Injection } \\
\text { well } \\
\text { number }\end{array}$ & $\begin{array}{c}\text { Sampled } \\
\text { well } \\
\text { number }\end{array}$ & $\begin{array}{c}\text { Distance } \\
\text { between } \\
\text { wells } \\
\text { (feet) }\end{array}$ & $\begin{array}{l}\text { Date of first } \\
\text { injection } \\
\text { (A) }\end{array}$ & $\begin{array}{c}\text { Date } \\
\text { sampled } \\
\text { (B) }\end{array}$ & $\begin{array}{c}\text { (A) } \\
\text { minus } \\
\text { (B) } \\
\text { (days) }\end{array}$ & $\begin{array}{c}\text { Apparent } \\
\text { breakthrough } \\
\text { velocity }^{1} \\
\text { (feet per day) }\end{array}$ \\
\hline $6-406$ & $\begin{array}{l}6-402 \\
6-405\end{array}$ & $\begin{array}{r}1,200 \\
500\end{array}$ & $06-01-85$ & $\begin{array}{l}08-24-91 \\
08-28-90 \\
08-30-91\end{array}$ & $\begin{array}{l}2,275 \\
1,914 \\
2,281\end{array}$ & $\begin{array}{c}0.53 \\
.22 \text { to } .26\end{array}$ \\
\hline $5-616$ & $5-605$ & 3,050 & $06-01-85$ & $09-07-91$ & 2,289 & 1.3 \\
\hline $5-620$ & $25-622$ & 700 & $06-01-85$ & $08-24-90$ & 1,910 & .37 \\
\hline $5-620$ & ${ }^{3} 5-622$ & 700 & $06-01-85$ & $08-29-91$ & 2,280 & .31 \\
\hline $5-624$ & $5-625$ & 300 & $05-28-85$ & $08-27-91$ & 2,282 & .13 \\
\hline $5-613$ & $5-601$ & 1,100 & $05-28-85$ & $08-30-90$ & 1,920 & $>.57$ \\
\hline
\end{tabular}

${ }^{1}$ Apparent breakthrough is defined as the detection of a 0.5 fraction of injected-water tracers in a sample.

${ }^{2}$ Sample was collected from a depth of 690 feet below land surface.

${ }^{3}$ Sample was collected from a depth of 605 feet below land surface.

about 44 Mgal per month (Brock and others, 1994). In addition, the velocity calculation assumes that transport of injected-water tracers is through homogeneous, isotropic granular geologic material (Freeze and Cherry, 1979, p. 390-391). The average breakthrough velocities of injected water in table 5 , therefore, may not represent actual velocities in discrete horizontal zones or alluvial channels within the aquifer.

Samples from wells 5-601, 5-618, 6-402, and 6-405 upgradient from the injection-well array all contained tracers of injected water and detectable concentrations of THM compounds (fig. 15). These data indicate that injection and pumping caused a reversal of the potentiometric-surface gradient and induced flow of injected water to the north. The effect of pumping is not apparent in the water-level contours (fig. 6) because the water levels were measured when production wells were not operating.

The detection of injected-water tracers but no detectable THM compounds [type (3) waters] in samples from wells 6-401 and 6-404 may indicate the influence of recharge from septic-system drainage from the Futureland subdivision or seepage from the unlined oxidation ponds at the FHWRP (figs. 2 and 15). That is, the lack of THM compounds in these samples indicates that the source of the tracers was not from HBRP injection. Potentiometric-surface data (fig. 6) indicate that these wells are downgradient (fig. 2) from the Futureland subdivision and the oxidation ponds.

Water samples with reportable components of irrigation-affected water include those from wells 5-604, 5-605, 5-621 (1990 samples), 5-625, 6-401, and 6-405 (table 4). These wells are in the region that has been influenced by irrigation-affected changes in dissolved-solids concentrations (White, 1983, fig. 32b, p. 60). Only the 1990 samples from wells 5-604 and 5-625 contained fractions of irrigation-affected water greater than or equal to 0.1 .

Water samples with fractions of saline-water solutes that are greater than 0.1 include those from wells 5-605, 6-401, 6-402, and 6-404 (table 4). These four wells are all located in the easternmost part of the HBRP area where the saturated thickness of the freshwater part of the Hueco bolson aquifer is smallest (White, 1983, fig. 36). 


\section{Distribution of Trihalomethane Compounds in Ground Water}

Total concentrations of all THM compounds, in injected-water samples before injection, ranged from $18,40($ ) to $34,600 \mathrm{ng} / \mathrm{L}$ (table 2). These concentrations were less than 35 percent of the current maximum contaminant level of $100,000 \mathrm{ng} / \mathrm{L}$ (or $100 \mu \mathrm{g} / \mathrm{L}$ ) for the sum of all THM compounds in a public water supply (U.S. Environmental Protection Agency, 199()). Ground-water samples from the closest observation wells to the injection wells, 5-621, 5-625, and 6-405, had total THM concentrations that ranged from 580 to $1,900 \mathrm{ng} / \mathrm{L}$. About 90 percent or more of the total THM concentrations in injected water have been lost during ground-water flow between injection and detection at these wells. By comparison, the fractions of injected water in samples from these wells ranged from 0.4 to 1 (table 4). These data indicate that changes in THM concentrations are greater than can be explained by dilution from advective and dispersive transport of injected water in ambient ground water.

The data also indicate that the transport of brominated THM compounds generally is attenuated relative to the transport of chlorinated THM compounds (fig. 16A-C). Concentrations of bromoform (1990) that ranged from $14,(0)(0)$ to 26,0$)(0) \mathrm{ng} / \mathrm{L}$ in injected-water samples had decreased to 60) ng/L at well 6-405 within about 3(x) $\mathrm{ft}$ of an injection well and to less than 20 $\mathrm{ng} / \mathrm{L}$ at wells 5-621 and 5-625 within about $300 \mathrm{ft}$ of injection wells (fig. 16A-C). Similar pattems of change were observed for dibromochloromethane. Chloroform and dichlorobromomethane concentrations are similar to or greater than their injected concentrations in samples at observation wells within 300 to $700 \mathrm{ft}$ of the closest injection well. The relative attenuation of the THM compounds increases in the following order:

Chloroform $=$ Dichlorobromomethane

$<$ Dibromochloromethane $<$ Bromoform.

The breakthrough of chloroform with injected water at a distance of about $700 \mathrm{ft}$ indicates that sorption probably does not control THM transport in the aquifer. The degree to which THM's and other nonpolar organic compounds are sorbed or "partition" into the organic material of aquifer solids is directly proportional to their octanol-water partition coefficients. The octanol-water partition coefficient of chloroform is 93 (table 6). If sorption was an important attenuating process for chloroform and other THM's, substantial atten- uation of chloroform relative to the tracers of injected water should have occurred.

Abiotic, aqueous hydrolysis reactions also are probably not responsible for attenuating the concentrations of brominated THM compounds relative to injected water and chloroform. In these reactions, the halogenated compound reacts with water resulting in an exchange of one of the halogen atoms of the compound with a hydroxyl group from the aqueous medium. The half-lives of chloroform and bromoform, when decomposed by abiotic hydrolysis reactions, are 3,500 and 687 years, respectively (table 6; Schwarzenbach and Giger, 1985). The lack of brominated THM compounds in ground water beyond about $300 \mathrm{ft}$ of the injection wells indicates that the process responsible for their decomposition proceeds at a much faster rate.

Microbial transformations are left as the most likely process responsible for the disappearance of brominated THM compounds from ground water. Retardation of bromoform and dibromochloromethane relative to chloroform and injected water was much greater in the HBRP area than at the Palo Alto baylands experiment in Califomia (Roberts and others, 1987). In the HBRP area, oxic or aerobic conditions prevailed in ground-water samples. Microcosm studies of water and sediment from the Palo Alto study indicated that all THM compounds were biotransformed under anaerobic but not aerobic conditions (Bouwer and others, 1981). These data and the preceding discussion indicate that the ground-water transport of brominated THM compounds in the HBRP area probably is attenuated by (1) anaerobic biotransformation in undefined, reduced redox zones of the aquifer, or (2) transformation by an unknown aerobic microbial or chemical process. The latter explanation is more likely, given the available data.

Decreases in chloroform and dichlorobromomethane concentrations between 1990 and 1991 water samples from wells 5-621, 5-625, and 6-405 contrast with increased fractions of injected water at these wells (tables 2,4). The concentrations of chloroform and dichlorobromomethane in 1991 water samples from these wells are similar to or greater than the range of concentrations in injected water from 1990 and 1991 samples (table 2). Changes in the chlorination of injected water would explain the variation in chloroform and dichlorobromomethane concentrations in ground water. 
Table 6. Physical and chemical properties of trihalomethane compounds

[Data from Montgomery and Welkom (1989); ${ }^{\circ} \mathrm{C}$, degrees Celsius; $\mathrm{mg} / \mathrm{L}$, milligrams per liter; $\mathrm{kPa}-\mathrm{m}^{3} / \mathrm{mol}$, kilopascal-cubic meters per mole; --, not determined]

\begin{tabular}{lcccc}
\hline \multicolumn{1}{c}{ Compound name } & $\begin{array}{c}\text { Average molecular } \\
\text { weight }\end{array}$ & Specific gravity & $\begin{array}{c}\text { Boiling point } \\
\left({ }^{\circ} \mathbf{C}\right)\end{array}$ & $\begin{array}{c}\text { Aqueous solubility } \\
\text { (mg/L) }\end{array}$ \\
\hline Chloroform & 119.38 & 1.49 & 61.7 & 8,200 \\
Dichlorobromomethane & 163.83 & 1.97 & 90.1 & 24,500 \\
Dibromochloromethane & 208.29 & 2.38 & 120 & 1,050 \\
Bromoform & 252.73 & 2.89 & 149.5 & 3,010 \\
& & & & Hydrolysis half-life \\
(years)
\end{tabular}

${ }^{1}$ At $20^{\circ} \mathrm{C}$ relative to the density of water at $4{ }^{\circ} \mathrm{C}$.

${ }^{2}$ At $25^{\circ} \mathrm{C}$.

Detectable concentrations of THM compounds were used with the EMMA method results in the preceding discussion to verify the presence of injected water in a water sample. Other potential sources of wastewater also contain substantially smaller concentrations of the THM compounds. These potential sources include seepage of wastewater from the oxidation ponds at the FHWRP, from the Futureland residential septic systems, and the seepage pond at the El Paso Natural Gas Plant.

Concentrations of THM compounds sampled from wastewater entering the FHWRP during a 5-day period in 1991 , using a detection limit of $5,000 \mathrm{ng} / \mathrm{L}$, were not detected on 3 days, and were detected at concentrations of 6,000 and $9,000 \mathrm{ng} / \mathrm{L}$ on days 3 and 4 of the test, respectively (Parkhill and others, 1991, table RM-2-4). This wastewater is the same as that stored in the oxidation ponds on the FHWRP site. Concentrations of THM compounds in seepage from the ponds also should have been diminished by biotransforming processes during infiltration. The large volume of wastewater seepage from the ponds and an ammonia concentration of $2.3 \mathrm{mg} / \mathrm{L}$ in a 1988 water sample from the adjacent well 6-503 (D.E. White, U.S. Geological Survey, written commun., 1988) indicate the prevalence of reduced conditions in the aquifer near the ponds. Reduced conditions favor the biotransformation of THM's to other species or compounds (Bouwer and McCarty, 1984). The septic-system effluent from the Futureland subdivision is not chlorinated before disposal and, therefore, should have smaller concentrations of THM compounds than in injected water. Detectable concentrations of THM compounds in ground water therefore should be associated only with injected water.

The detection of chloroform at $140 \mathrm{ng} / \mathrm{L}$ in water from well 5-303 indicates the possible origin of traces of chloroform from an unknown source (table 2). Well 5-303 is about $1 \mathrm{mi}$ upgradient from the HBRP area, eliminating injected water as a potential source of the chloroform (figs. 2 and 6). The well is on property adjacent to the El Paso Natural Gas Plant and the former 
dairy farm. It is unknown whether the sewage pond or irrigation waters were chlorinated or contained chloroform before their disposal. These data indicate that detection of chloroform, independent of the EMMA method results, is not diagnostic of the presence of injected water in a ground-water sample.

\section{SUMMARY}

Several laterally continuous layers of sand and gravel or silt and clay with smaller discontinuous interbeds of sand and clay are the principal lithologies in the freshwater part of the aquifer near the Hueco Bolson Recharge Project (HBRP) area. The sand and gravel units are the chief water-yielding strata of the aquifer. The overall lithologic continuity indicates that hydraulic continuity exists between the injection and production wells. The vertically averaged hydraulic conductivity of sand layers in the aquifer near the HBRP area ranged from 21 to $88 \mathrm{ft} / \mathrm{d}$. Hydraulic conductivity in the aquifer is largest along a zone between the southwest corner and the north-central part of the HBRP area and decreases across the HBRP area toward the south and west. The potentiometric-surface gradient throughout the area sloped toward the south and southwest during January 1990. Average linear ground-water velocities near the zone of largest hydraulic conductivity were about $1.3 \mathrm{ft} / \mathrm{d}$ near wells 5 602 and 5-618 and 1.4 ft/d near wells 5-625 and 5-603. Average linear ground-water velocities were substantially smaller near wells 6-402 and 6-405 and near wells 5-621 and 5-604.

The principal source of human-affected recharge to the aquifer near the HBRP area is reclaimed-water injection. About 8.07 billion gal of treated wastewater were injected into the aquifer through 10 injection wells between May 1985 and March 1991. Other potential sources of human-affected recharge include irrigation-affected water from a former dairy farm on an adjacent property and seepage from unlined oxidation ponds at the FHWRP.

The numerical method, end-member mixing analysis (EMMA), was used to define fractional components of injected water and other solute sources to ground-water chemistry. Chloride, nitrate, and $\delta^{18} \mathrm{O}$ were the conservative tracers used to differentiate among potential sources of recharge and solutes to ground water. The major end members that contribute to ground-water chemistry at the HBRP area are injected water, irrigation-affected water, saline ground water, and freshwater. EMMA-predicted concentrations of solute tracers closely agreed with the observed analytical data from ground-water samples.

Injected-water tracers were present in fractions greater than 0.10 in water samples of three types: (1) those with total THM compound concentrations greater than $500 \mathrm{ng} / \mathrm{L}$, (2) those with total THM compound concentrations ranging from 20 to $500 \mathrm{ng} / \mathrm{L}$, and (3) those with no detectable THM compounds. Water samples of type (1) are from wells within $700 \mathrm{ft}$ of an injection well. Most water samples of type (2) are from wells that range in distance from about 300 to $2,900 \mathrm{ft}$ from the nearest injection well. Type (3) water samples had no detectable THM compounds and do not represent injected water. Type (3) water was found in wells 6-401 and 6-404, northeast and east of the HBRP area; sources of the tracers in these wells may be recharge from septic systems or oxidation pond seepage. The apparent breakthrough velocity of injected water in the aquifer ranged from $0.13 \mathrm{ft} / \mathrm{d}$ between wells 5-624 and 5-625 to $1.3 \mathrm{ft} / \mathrm{d}$ between wells 5-616 and 5-605. Irrigation-affected water and saline water also were identified in fractions greater than 0.1 in water from several wells.

The transport of bromoform and dibromochloromethane in ground water is attenuated relative to injected water, chloroform, and dichlorobromomethane. Chloroform and dichlorobromomethane are not attenuated in their transport relative to injected water. The brominated THM compounds probably are attenuated in ground water transport by: (1) anaerobic biotransformation in undefined, reduced redox zones of the aquifer, or (2) transformation by an unknown aerobic microbial or chemical process.

\section{REFERENCES CITED}

Barber, L.B. II, 1985, Geochemistry of organic and inorganic compounds in a sewage contaninated aquifer, Cape Cod, Massachusetts: Boulder, Co., University of Colorado, unpub. M.S. thesis, $169 \mathrm{p}$.

Bassett, R.L., 1976, The geochemistry of boron in geothermal waters: Stanford, Calif., Stanford University, unpub. Ph.D. dissertation, $220 \mathrm{p}$.

1990, A critical evaluation of the available measurements for the stable isotopes of boron: Applied Geochemistry, v. 5, p. 541-554.

Bouwer, E.J., and McCarty, P.L., 1984, Modelling of trace organics biotransformation in the subsurface: Ground Water, v. 22, no. 4, p. 433-440. 
Bouwer, E.J., Rittman, B.E., and McCarty, P.L., 1981, Anaerobic degradation of halogenated 1- and 2-carbon organic compounds: Environmental Science and Technology, v. 15 , no. 5 , p. 596-599.

Brock, R.D., Buszka, P.M., and Godsy, E.M., 1994, Hydrogeologic and water-quality data from wells near the Hueco Bolson Recharge Project area, El Paso, Texas, 1990 and 1991: U.S. Geological Survey Open-File Report 94-329, 85 p.

Christopherson, Nils, Neal, Colin, Hooper, R.P., Vogt, R.D., and Andersen, Sjur, 1990, Modelling streamwater chemistry as a mixture of soilwater end members--a step towards second-generation acidification models: Journal of Hydrology, v. 116, p. 307-320.

Curtis, G.P., Roberts, P.V., and Reinhard, Martin, 1986, A natural gradient experiment on solute transport in a sand aquifer--4. Sorption of organic solutes and its influence on mobility: Water Resources Research, v. 22 , no. 13 , p. 2,059-2,067.

Davis, S.N., Campbell, D.J., Bentley, H.J., and Flynn, T.J., 1985, Ground-water tracers: Worthington, Ohio, National Water Well Association, 200 p.

Draper, N.R., and Smith, Harry, 1981, Applied regression analysis ( $2 \mathrm{~d}$ ed.): New York, Wiley-Interscience, $709 \mathrm{p}$.

Fontes, J.C., 1980, Environmental isotopes in groundwater hydrology, chap. 3, in Fritz, Peter, and Fontes, J.C., eds., Handbook of environmental isotope geochemistry, v. 1, The terrestrial environment, A: Amsterdam, The Netherlands, Elsevier Scientific Publishing Co., p. 75140.

Freeze, R.A., and Cherry, J.A., 1979, Groundwater: Englewood Cliffs, New Jersey, Prentice-Hall, 604 p.

Fritz, Peter, and Fontes, J.C., 1980, Introduction, in Fritz, Peter, and Fontes, J.C., eds., Handbook of environmental isotope geochemistry, v. 1, The terrestrial environment, A: Amsterdam, The Netherlands, Elsevier Scientific Publishing Co., p. 1-19.

Garza, Sergio, Weeks, E.P., and White, D.E., 1980, Appraisal of potential for injection-well recharge of the Hueco bolson with treated sewage effluent--preliminary study of the northeast E1 Paso area, Texas: U.S. Geological Survey Open-File Report 80-1106, 39 p.

Gerba, C.P., and Goyal, S.M., 1985, Pathogen removal from wastewater during groundwater recharge, in Asano, Takashi, ed., Artificial recharge of groundwater: Boston, Butterworth Publishers, p. 283-318.

Hooper, R.P., Christopherson, Nils, and Peters, N.E., 1990, Modeling streamwater chemistry as a mixture of soilwater end members--an application to the Panola Mountain Catchment, Georgia, U.S.A.: Journal of Hydrology, v. 116, p. 321-343.

Hoy, R.N. and Gross, G.W., 1982, A baseline study of oxygen-18 and deuterium in the Roswell, New Mexico, groundwater basin: New Mexico Water Resources Research Institute Report 144, 95 p.

Knorr, D.B., and Cliett, T., 1985, Proposed groundwater recharge at El Paso, Texas, in Asano, Takashi., ed., Artificial recharge of groundwater: Boston, Butterworth Publishers, p. 425-480.

Kreitler, C.W., and Jones, D.C., 1975, Natural soil nitrate-the cause of the nitrate contamination in Runnels County, Texas: Ground Water, v. 13, no. 1, p. 53-61.

Larkin, T.J., and Bomar, G.W., 1983, Climatic atlas of Texas: Texas Department of Water Resources Report LP-192, p. 2-3.

Lee Wilson and Associates, 1991, Solute transport model of Hueco Bolson Recharge Project: Research memorandum no. 3, prepared for El Paso Water Utilities-Public Service Board, $148 \mathrm{p}$.

Lloyd, J.W., Howard, K.W.F., Pacey, N.R., and Tellam, J.H., 1982 , The value of iodide as a parameter in the chemical characterization of groundwaters: Journal of Hydrology, v. 57, p. 247-265.

Mackay, D.M., Freyberg, D.L., and Roberts, P.V., 1986, A natural gradient experiment on solute transport in a sand aquifer- -1 . Approach and overview of plume movement: Water Resources Research, v. 22, no. 13, p. 2,017-2,029.

Meyer, W.R., 1976, Digital model for simulated effects of ground-water pumping in the Hueco bolson, El Paso area, Texas, New Mexico, and Mexico: U.S. Geological Survey Water-Resources Investigations Report 58$75,31 \mathrm{p}$.

Montgomery, J.H., and Welkom, L.M., 1989, Ground water chemicals desk reference: Chelsea, Mich., Lewis Publishers, $640 \mathrm{p}$.

Palmer, M.R., Spivack, A.J., and Edmond, J.M., 1987, Temperature and $\mathrm{pH}$ controls over isotopic fractionation during adsorption of boron on marine clay: Geochimica et Cosmochimica Acta, v. 51, p. 2,3192,323 .

Parkhill, Smith, and Cooper, Inc., 1990, Plant and well data, November, 1990, Hueco Bolson Recharge Demonstration Project: Prepared for El Paso Water Utilities-Public Service Board, data from 2 diskettes.

1991, Evaluation of priority pollutants--Hueco Bolson Recharge Demonstration Project: Research memorandum no. 2, prepared for El Paso Water Utilities-Public Service Board, $65 \mathrm{p}$.

Richardson, G.B., 1909, Geologic atlas of the United States, El Paso folio, Texas: U.S. Geological Survey Folio No. $166,14 \mathrm{p}$.

Roberts, P.V., Goltz, M.N., and Mackay, D.M., 1986, A natural gradient experiment on solute transport in a sand aquifer--3. Retardation estimates and mass balances for organic solutes: Water Resources Research, v. 22, no. 13 , p. 2,047-2,058. 
Roberts, P.V., Reinhard, Martin, Hopkins, G.D., and Summers, R.S., 1987, Advection-dispersion-sorption models for simulating the transport of organic contaminants, in Ward, C.H., Giger, W., and McCarty, P.L., eds.. Ground-water quality: New York, Wiley, p. 425444.

Schwarzenbach, R.P., and Giger, W., 1985, Behavior and fate of halogenated hydrocarbons in ground water, in Ward, C.H., Giger, W., and McCarty, P.L., eds., Ground-water quality: New York, Wiley, p. 446-471.

Schwarzenbach, R.P., Giger, W., Hoehn, E., and Schreiner, J.K., 1983, Behavior of organic compounds during infiltration of river water to groundwater: Environmental Science and Technology, v. 17, p. 472-479.

Thurman, E.M., 1985, Organic geochemistry of natural waters: Dordrecht, The Netherlands, Martinus Nijhoff/Dr. W. Junk Publishers, 497 p.

Treweek, G.P., 1985, Pretreatment processes for ground water recharge, in Asano, Takashi, ed., Artificial recharge of groundwater: Boston, Butterworth Publishers, p. 205-248.

U.S. Environmental Protection Agency, 1990, Fact sheet-Drinking water regulations under the safe drinking water act. December, 199(): Washington, D.C., Criteria and Standards Division, Office of Drinking Water, $45 \mathrm{p}$.
Waggott, A., 1969, An investigation of the potential problem of increasing boron concentrations in rivers and water courses: Water Research, v. 3, p. 749-765.

White, D.E., 1983, Summary of hydrologic information in the El Paso, Texas, area with emphasis on ground-water studies: U.S. Geological Survey Open-File Report 83775, 77 p. (also published as Texas Department of Water Resources report 300).

White, D.E., and Sladek, G.J., 1990, Summary of data from the 1981-83 pilot study and 1985-89 operations of the Hueco Bolson Recharge Project, northeast El Paso, Texas: U.S. Geological Survey Open-File Report 90$175,38 \mathrm{p}$.

Whittemore, D.O., 1988, Bromide in ground-water studies, in Geochemistry and Analytical Determination, Proceedings of the Ground Water Geochemistry Conference, Denver, Colorado, February 16-18, 1988: Dublin, Ohio, National Water Well Association Publishing Co., p. 339-359.

Wolfram, Steven, 1988, Mathematical--a system for doing mathematics by computer: New York, AddisonWesley, $749 \mathrm{p}$. 
Table 2. Selected water-quality properties and constituent concentrations in injected water and ground water in and near the Hueco Bolson Recharge Project area

$\left[{ }^{\circ} \mathrm{C}\right.$, degrees Celsius; mg/L, milligrams per liter; $\mathrm{N}$, nitrogen; $\mathrm{B}$, boron; $\mu \mathrm{g} / \mathrm{L}$, micrograms per liter; --, no data; ng/L, nanograms per liter; THM, trihalomethane; <, less than]

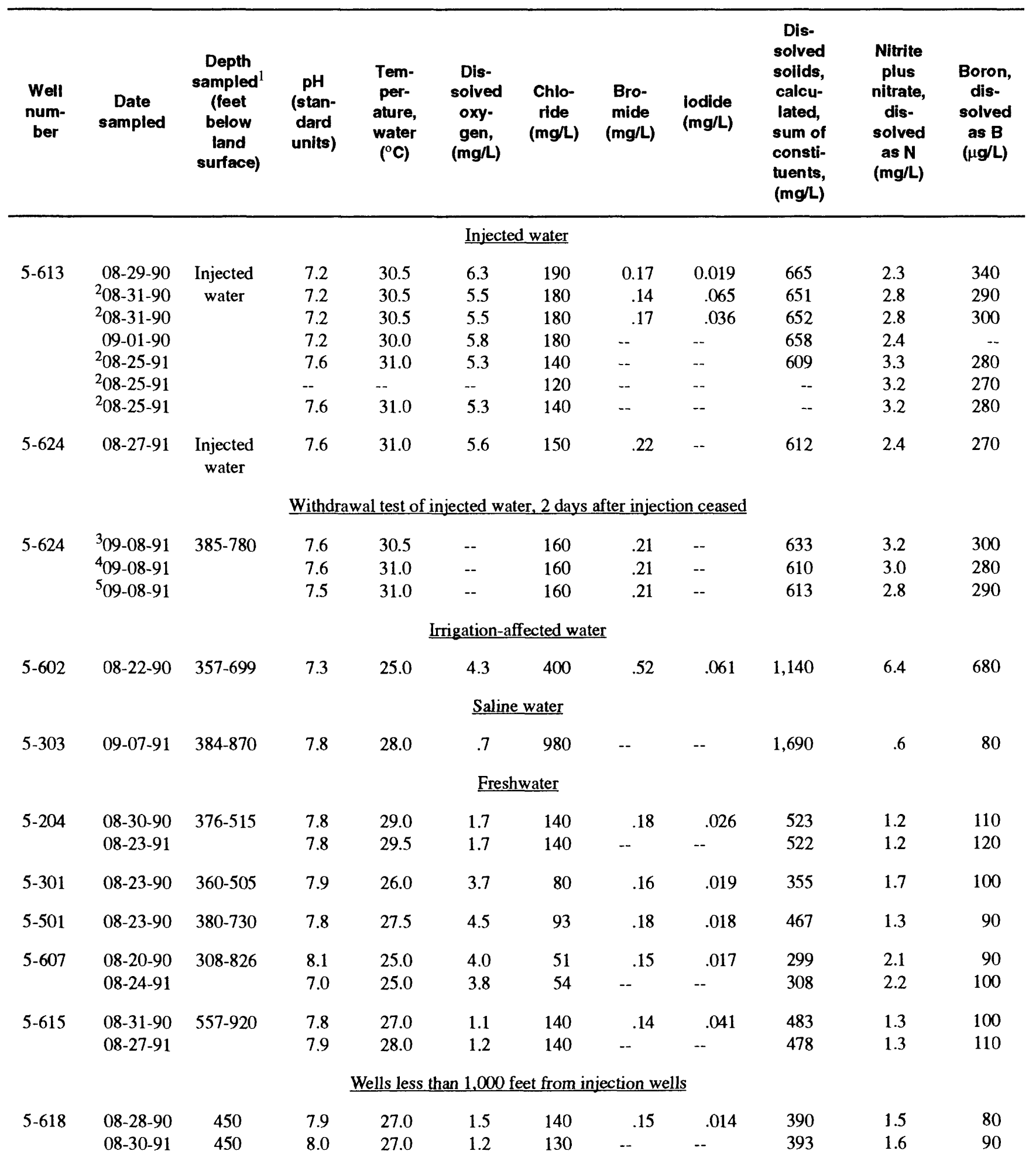


Table 2. Selected water-quality properties and constituent concentrations in injected water and ground water in and near the Hueco Bolson Recharge Project area--Continued

\begin{tabular}{|c|c|c|c|c|c|c|c|c|c|c|c|}
\hline $\begin{array}{c}\text { Well } \\
\text { num- } \\
\text { ber }\end{array}$ & $\begin{array}{c}\text { Date } \\
\text { sampled }\end{array}$ & $\begin{array}{l}\text { Depth } \\
\text { sampled } \\
\text { (feet } \\
\text { below } \\
\text { land } \\
\text { surface) }\end{array}$ & $\begin{array}{c}\text { pH } \\
\text { (stan- } \\
\text { dard } \\
\text { units) }\end{array}$ & $\begin{array}{l}\text { Tem- } \\
\text { per- } \\
\text { ature, } \\
\text { water } \\
\left({ }^{\circ} \mathrm{C}\right)\end{array}$ & $\begin{array}{c}\text { Dis- } \\
\text { solved } \\
\text { oxy- } \\
\text { gen, } \\
\text { (mgll) }\end{array}$ & $\begin{array}{l}\text { Chlo- } \\
\text { ride } \\
\text { (mg/L) }\end{array}$ & $\begin{array}{l}\text { Bro- } \\
\text { mide } \\
\text { (mg/L) }\end{array}$ & $\begin{array}{l}\text { lodide } \\
\text { (mg/L) }\end{array}$ & $\begin{array}{l}\text { Dis- } \\
\text { solved } \\
\text { solids, } \\
\text { calcu- } \\
\text { lated, } \\
\text { sum of } \\
\text { consti- } \\
\text { tuents, } \\
\text { (mg/L) }\end{array}$ & $\begin{array}{c}\text { Nitrite } \\
\text { plus } \\
\text { nitrate, } \\
\text { dis- } \\
\text { solved } \\
\text { as } N \\
(\mathrm{mg} / \mathrm{L})\end{array}$ & $\begin{array}{c}\text { Boron, } \\
\text { dis- } \\
\text { solved } \\
\text { as B } \\
(\mu \mathrm{g} / \mathrm{L})\end{array}$ \\
\hline \multicolumn{12}{|c|}{ Wells less than 1,000 feet from injection well--Continued } \\
\hline \multirow[t]{4}{*}{$5-621$} & $08-25-90$ & ${ }^{6} 430$ & 7.6 & 25.5 & 5.9 & 160 & 0.19 & 0.029 & 636 & 2.8 & 300 \\
\hline & $08-29-90$ & ${ }^{6} 640$ & -- & -- & $\ldots$ & 160 & .21 & .028 & 645 & 2.8 & 290 \\
\hline & $08-29-91$ & ${ }^{6} 430$ & 7.3 & 25.5 & 2.9 & 140 & -- & -- & 611 & 3.3 & 340 \\
\hline & $08-29-91$ & ${ }^{6} 640$ & 7.3 & 25.5 & 2.9 & 140 & - & -- & 609 & 3.3 & 360 \\
\hline \multirow{2}{*}{$5-622$} & $08-29-91$ & ${ }^{6} 430$ & 7.6 & 27.0 & 2.6 & 150 & - & -- & 520 & 2.2 & 170 \\
\hline & $08-29-91$ & ${ }^{6} 605$ & 7.6 & 27.0 & 2.6 & 140 & -- & -- & 508 & 2.2 & 170 \\
\hline \multirow[t]{4}{*}{$5-625$} & $08-27-90$ & ${ }^{6} 430$ & 7.6 & 27.0 & 4.7 & 170 & .21 & .028 & 635 & 2.9 & 260 \\
\hline & $08-27-90$ & ${ }^{6} 605$ & 7.6 & 27.0 & 4.7 & 150 & .21 & .030 & 625 & 2.8 & 260 \\
\hline & $08-27-91$ & ${ }^{6} 430$ & 7.6 & 26.5 & 4.5 & 140 & .25 & -- & 614 & 3.1 & 290 \\
\hline & $08-27-91$ & ${ }^{6} 605$ & 7.6 & 26.5 & 4.5 & 160 & -- & -. & 634 & 3.0 & 280 \\
\hline \multirow[t]{3}{*}{$5-626$} & $08-27-90$ & ${ }^{6} 430$ & 7.9 & 27.0 & 2.3 & 110 & .16 & .024 & 408 & 1.8 & 120 \\
\hline & $08-28-90$ & ${ }^{6} 605$ & 7.9 & 27.0 & 2.3 & 120 & .03 & .007 & 412 & 1.7 & 120 \\
\hline & $08-27-91$ & ${ }^{6} 430$ & 7.8 & 27.0 & 1.4 & 130 & .18 & -- & 430 & 1.7 & 120 \\
\hline $5-601$ & $08-26-91$ & & 7.8 & 26.0 & 5.9 & 130 & -- & -- & 561 & 2.6 & 270 \\
\hline \multirow[t]{3}{*}{$5-603$} & ${ }^{2} 08-21-90$ & $352-657$ & 7.9 & 26.5 & 2.4 & 90 & .17 & .022 & 42.5 & 1.5 & 120 \\
\hline & ${ }^{2} 08-21-90$ & & 7.9 & 26.5 & 2.4 & 89 & .17 & .022 & 424 & 1.5 & 110 \\
\hline & $08-25-91$ & & 7.9 & 27.0 & 2.3 & 84 & -- & -- & 420 & 1.5 & 120 \\
\hline $5-604$ & $08-22-90$ & $382-802$ & 7.8 & 25.5 & 4.0 & 190 & .29 & .029 & 527 & 3.5 & 120 \\
\hline \multirow[t]{3}{*}{$5-605$} & ${ }^{2} 09-01-90$ & $343-769$ & 7.9 & 25.0 & 4.2 & 240 & -- & -. & 543 & 2.0 & -- \\
\hline & ${ }^{2} 09-01-90$ & & 7.9 & 25.0 & 4.2 & 240 & .23 & .017 & 543 & 2.0 & 80 \\
\hline & $09-07-91$ & & 8.0 & 25.5 & 4.3 & 240 & -- & -- & 534 & 2.0 & 90 \\
\hline $6-401$ & $09-09-91$ & $348-451$ & 7.8 & 24.0 & -- & 270 & -- & -- & 568 & 2.3 & 80 \\
\hline \multirow[t]{5}{*}{$6-402$} & ${ }^{2} 09-01-90$ & $363-670$ & 7.9 & 25.0 & 4.9 & 290 & .26 & .019 & 616 & 1.8 & 80 \\
\hline & ${ }^{2} 09-01-90$ & & 7.9 & 25.0 & 4.9 & 290 & .26 & .019 & 614 & 1.8 & 70 \\
\hline & ${ }^{2} 08-24-91$ & & 7.9 & 26.0 & 4.0 & 260 & -- & -- & 591 & 1.8 & 90 \\
\hline & ${ }^{2} 08-24-91$ & & 7.9 & 26.0 & 4.0 & 270 & -- & -- & -- & 1.8 & 90 \\
\hline & ${ }^{2} 08-24-91$ & & -- & -- & - & 240 & -- & - & -- & 1.8 & 90 \\
\hline $6-404$ & $09-06-91$ & -- & 7.9 & 25.0 & 5.2 & 360 & -- & -- & -- & 2.0 & 80 \\
\hline
\end{tabular}


Table 2. Selected water-quality properties and constituent concentrations in injected water and ground water in and near the Hueco Bolson Recharge Project area--Continued

\begin{tabular}{|c|c|c|c|c|c|c|c|c|c|c|}
\hline $\begin{array}{c}\text { Well } \\
\text { num- } \\
\text { ber }\end{array}$ & $\begin{array}{c}\text { Date } \\
\text { sampled }\end{array}$ & $\begin{array}{c}\text { Depth } \\
\text { sampled } \\
\text { (feet below } \\
\text { land surface) }\end{array}$ & $\begin{array}{l}\text { Bromo- } \\
\text { form, } \\
\text { total } \\
\text { (ng/L) }\end{array}$ & $\begin{array}{c}\text { Dibromo- } \\
\text { chloro- } \\
\text { methane, } \\
\text { total } \\
\text { (ng/L) }\end{array}$ & $\begin{array}{l}\text { Chloro- } \\
\text { form, } \\
\text { total } \\
\text { (ng/L) }\end{array}$ & $\begin{array}{c}\text { Dichloro- } \\
\text { bromo- } \\
\text { methane, } \\
\text { total } \\
\text { (ng/L) }\end{array}$ & $\begin{array}{l}\text { THM, } \\
\text { total } \\
\text { (ng/L) }\end{array}$ & $\begin{array}{c}\delta^{18} \mathrm{O} \\
\text { stable } \\
\text { Isotope } \\
\text { ratio } \\
\text { (per } \mathrm{mil} \text { ) }\end{array}$ & $\begin{array}{c}\delta \mathrm{D} \\
\text { stable } \\
\text { Isotope } \\
\text { ratio } \\
\text { (per mll) }\end{array}$ & $\begin{array}{c}\delta^{11} B \\
\text { stable } \\
\text { Isotope } \\
\text { ratlo } \\
\text { (per mil) }\end{array}$ \\
\hline \multicolumn{11}{|c|}{ Injected water } \\
\hline $5-613$ & $\begin{array}{c}08-29-90 \\
08-31-90 \\
08-31-90 \\
09-01-90 \\
08-25-91 \\
08-25-91 \\
08-25-91\end{array}$ & $\begin{array}{l}\text { Injected } \\
\text { water }\end{array}$ & $\begin{array}{r}20,000 \\
14,000 \\
15,000 \\
22,000 \\
20,000 \\
-- \\
--\end{array}$ & $\begin{array}{r}4,900 \\
3,800 \\
3,900 \\
4,100 \\
6,500 \\
-- \\
--\end{array}$ & $\begin{array}{r}190 \\
210 \\
200 \\
190 \\
400 \\
-- \\
--\end{array}$ & $\begin{array}{r}510 \\
340 \\
340 \\
410 \\
740 \\
-- \\
--\end{array}$ & $\begin{array}{c}25,600 \\
18,400 \\
19,400 \\
26,700 \\
27,600 \\
-- \\
--\end{array}$ & $\begin{array}{l}-9.30 \\
-9.00 \\
-9.10 \\
-9.10 \\
-9.35 \\
-9.30 \\
-9.30\end{array}$ & $\begin{array}{l}-64.5 \\
-63.5 \\
-63.0 \\
-66.0 \\
-66.5 \\
-65.0 \\
-65.0\end{array}$ & $\begin{array}{l}10.6 \\
10.1 \\
-- \\
-- \\
6.0 \\
-- \\
--\end{array}$ \\
\hline $5-624$ & $08-27-91$ & $\begin{array}{c}\text { Injected } \\
\text { water }\end{array}$ & 26,000 & 7,400 & 380 & 820 & 34,600 & -9.35 & -65.5 & 6.3 \\
\hline \multicolumn{11}{|c|}{ Withdrawal test of injected water, 2 days after injection ceased } \\
\hline $5-624$ & $\begin{array}{l}{ }^{3} 09-08-91 \\
{ }^{4} 09-08-91 \\
{ }^{5} 09-08-91\end{array}$ & $385-780$ & $\begin{array}{l}54 \\
56 \\
85\end{array}$ & $\begin{array}{l}<20 \\
<20 \\
<20\end{array}$ & $\begin{array}{l}275 \\
287 \\
271\end{array}$ & $\begin{array}{l}<20 \\
<20 \\
<20\end{array}$ & $\begin{array}{l}330 \\
340 \\
360\end{array}$ & $\begin{array}{l}-9.25 \\
-9.05 \\
-9.25\end{array}$ & $\begin{array}{l}-65.5 \\
-65.0 \\
-66.0\end{array}$ & $\begin{array}{l}-- \\
-- \\
--\end{array}$ \\
\hline \multicolumn{11}{|c|}{ Irrigation-affected water } \\
\hline $5-602$ & $08-22-90$ & $357-699$ & $<20$ & $<20$ & $<20$ & $<20$ & $<20$ & -9.30 & -65.5 & 43.3 \\
\hline \multicolumn{11}{|c|}{$\underline{\text { Saline water }}$} \\
\hline $5-303$ & $09-07-91$ & $384-870$ & $<20$ & 20 & 140 & 20 & 180 & -10.25 & -71.5 & 17.8 \\
\hline \multicolumn{11}{|c|}{ Freshwater } \\
\hline $5-204$ & $\begin{array}{l}08-30-90 \\
08-23-91\end{array}$ & $376-515$ & $\begin{array}{l}<20 \\
<20\end{array}$ & $\begin{array}{l}<20 \\
<20\end{array}$ & $\begin{array}{l}<20 \\
<20\end{array}$ & $\begin{array}{l}<20 \\
<20\end{array}$ & $\begin{array}{l}<20 \\
<20\end{array}$ & $\begin{array}{l}-9.95 \\
-9.90\end{array}$ & $\begin{array}{l}-69.5 \\
-70.0\end{array}$ & $\begin{array}{l}15.6 \\
16.7\end{array}$ \\
\hline $5-301$ & $08-23-90$ & $360-505$ & $<20$ & $<20$ & $<20$ & $<20$ & $<20$ & -9.70 & -67.0 & 19.1 \\
\hline $5-501$ & $08-23-90$ & $380-730$ & $<20$ & $<20$ & $<20$ & $<20$ & $<20$ & -9.70 & -65.5 & 14.9 \\
\hline $5-607$ & $\begin{array}{c}08-20-90 \\
08-24-91\end{array}$ & $308-826$ & $\begin{array}{l}<20 \\
<20\end{array}$ & $\begin{array}{l}<20 \\
<20\end{array}$ & $\begin{array}{l}<20 \\
<20\end{array}$ & $\begin{array}{l}<20 \\
<20\end{array}$ & $\begin{array}{l}<20 \\
<20\end{array}$ & $\begin{array}{l}-9.60 \\
-9.60\end{array}$ & $\begin{array}{l}-66.5 \\
-68.0\end{array}$ & $\begin{array}{l}19.6 \\
21.5\end{array}$ \\
\hline $5-615$ & $\begin{array}{l}08-31-90 \\
08-27-91\end{array}$ & $557-920$ & $\begin{array}{l}<20 \\
<20\end{array}$ & $\begin{array}{l}<20 \\
<20\end{array}$ & $\begin{array}{l}<20 \\
<20\end{array}$ & $\begin{array}{l}<20 \\
<20\end{array}$ & $\begin{array}{l}<20 \\
<20\end{array}$ & $\begin{array}{r}-10.05 \\
-10.10\end{array}$ & $\begin{array}{l}-70.5 \\
-70.5\end{array}$ & $\begin{array}{l}14.7 \\
13.3\end{array}$ \\
\hline \multicolumn{11}{|c|}{ Wells less than 1,000 feet from injection wells } \\
\hline $5-618$ & $\begin{array}{l}08-28-90 \\
08-30-91\end{array}$ & $\begin{array}{l}450 \\
450\end{array}$ & $\begin{array}{l}<20 \\
<20\end{array}$ & $\begin{array}{l}<20 \\
<20\end{array}$ & $\begin{array}{r}70 \\
110\end{array}$ & $\begin{array}{r}90 \\
150\end{array}$ & $\begin{array}{l}160 \\
260\end{array}$ & $\begin{array}{l}-9.50 \\
-9.75\end{array}$ & $\begin{array}{l}-69.0 \\
-67.5\end{array}$ & $\begin{array}{l}14.4 \\
15.3\end{array}$ \\
\hline $5-621$ & $\begin{array}{l}08-25-90 \\
08-29-90 \\
08-29-91 \\
08-29-91\end{array}$ & $\begin{array}{l}{ }^{6} 430 \\
{ }^{6} 640 \\
{ }^{6} 430 \\
{ }_{6}^{6} 640\end{array}$ & $\begin{array}{l}<20 \\
<20 \\
<20 \\
<20\end{array}$ & $\begin{array}{r}<20 \\
<20 \\
<20 \\
30\end{array}$ & $\begin{array}{l}590 \\
620 \\
430 \\
400\end{array}$ & $\begin{array}{r}1,300 \\
1,300 \\
560 \\
530\end{array}$ & $\begin{array}{r}1,900 \\
1,900 \\
990 \\
960\end{array}$ & $\begin{array}{l}-9.35 \\
-9.35 \\
-9.20 \\
-9.20\end{array}$ & $\begin{array}{l}-64.5 \\
-67.5 \\
-64.5 \\
-65.5\end{array}$ & $\begin{array}{l}5.4 \\
9.1 \\
-- \\
--\end{array}$ \\
\hline
\end{tabular}


Table 2. Selected water-quality properties and constituent concentrations in injected water and ground water in and near the Hueco Bolson Recharge Project area--Continued

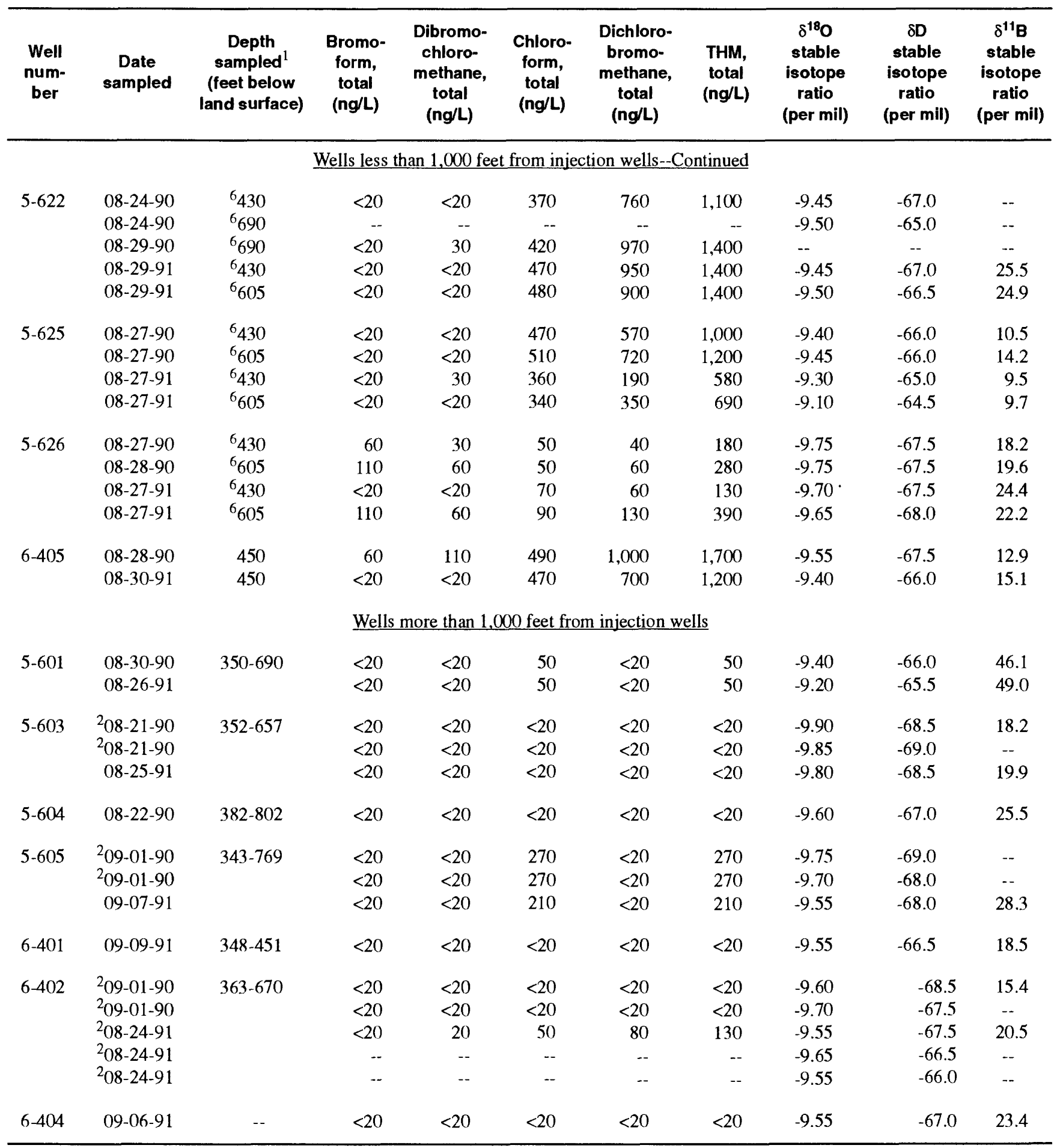

\footnotetext{
${ }^{1}$ Upper depth of sampled interval represents the most recent recorded depth to the water table (Brock and others, 1994).

2 Replicate samples.

${ }^{3}$ Pumping time, 30 minutes.

${ }^{4}$ Pumping time, 3 hours, 30 minutes.

5 Pumping time, 6 hours, 30 minutes.

${ }^{6}$ Depth of sample collection in well using a thief sampler.
} 